ARTICLE

DOI: $10.1038 / \mathrm{s} 41467-018-06728-7$

\title{
Interfacing nickel nitride and nickel boosts both electrocatalytic hydrogen evolution and oxidation reactions
}

Fuzhan Song ${ }^{1}$, Wei Li (i) ${ }^{1}$, Jiaqi Yang ${ }^{2}$, Guanqun Han $^{1}$, Peilin Liao ${ }^{2}$ \& Yujie Sun (i) ${ }^{1,3}$

Electrocatalysts of the hydrogen evolution and oxidation reactions (HER and HOR) are of critical importance for the realization of future hydrogen economy. In order to make electrocatalysts economically competitive for large-scale applications, increasing attention has been devoted to developing noble metal-free HER and HOR electrocatalysts especially for alkaline electrolytes due to the promise of emerging hydroxide exchange membrane fuel cells. Herein, we report that interface engineering of $\mathrm{Ni}_{3} \mathrm{~N}$ and $\mathrm{Ni}$ results in a unique $\mathrm{Ni}_{3} \mathrm{~N} / \mathrm{Ni}$ electrocatalyst which exhibits exceptional HER/HOR activities in aqueous electrolytes. A systematic electrochemical study was carried out to investigate the superior hydrogen electrochemistry catalyzed by $\mathrm{Ni}_{3} \mathrm{~N} / \mathrm{Ni}$, including nearly zero overpotential of catalytic onset, robust long-term durability, unity Faradaic efficiency, and excellent CO tolerance. Density functional theory computations were performed to aid the understanding of the electrochemical results and suggested that the real active sites are located at the interface between $\mathrm{Ni}_{3} \mathrm{~N}$ and $\mathrm{Ni}$.

\footnotetext{
${ }^{1}$ Department of Chemistry \& Biochemistry, Utah State University, Logan, UT 84322, USA. ${ }^{2}$ School of Materials Engineering, Purdue University, West Lafayette, IN 47907, USA. ${ }^{3}$ Department of Chemistry, University of Cincinnati, Cincinnati, OH 45221, USA. These authors contributed equally: Fuzhan Song and Wei Li. Correspondence and requests for materials should be addressed to P.L. (email: Ipl@purdue.edu) or to Y.S. (email: yujie.sun@uc.edu)
} 
$\mathrm{H}$ ydrogen $\left(\mathrm{H}_{2}\right)$ has long been advocated as a clean and carbon-neutral energy carrier in the field of renewable energy catalysis, in that $\mathrm{H}_{2}$ can be produced from water electrolysis with renewable energy inputs, like solar and wind power, and its utilization in hydrogen fuel cells will produce electricity with water as the sole product ${ }^{1}$. The success of a future hydrogen economy strongly depends on the efficient $\mathrm{H}_{2}$ production and utilization, which includes the hydrogen evolution and oxidation reactions (HER and HOR $)^{2-5}$. Owing to the multiproton multi-electron nature of both HER and HOR, electrocatalysts are indispensable to drive the two reactions to achieve industrially relevant rates. Pt-based electrocatalysts exhibit the best performance for $\mathrm{H}_{2}$ evolution in strongly acidic electrolytes ${ }^{6}$, however their HER activities are substantially diminished under alkaline conditions. Since no Earth-abundant electrocatalysts of water oxidation can survive under strongly acidic conditions and match the rates of Pt-based HER electrocatalysts so far, an increasing attention has been shifted towards $\mathrm{H}_{2}$ evolution in alkaline media, in which a number of low-cost HER electrocatalysts start to rival Pt-based HER electrocatalysts. The same scenario occurs for the $\mathrm{H}_{2}$ oxidation reaction. Pt is still the stateof-the-art HOR electrocatalyst under acidic conditions for the application of proton exchange membrane fuel cells

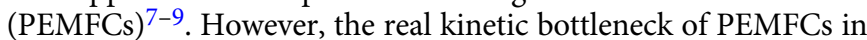
acidic electrolytes is the cathodic $\mathrm{O}_{2}$ reduction reaction (ORR), which requires a large amount of unaffordable Pt. In order to develop economically attractive hydrogen fuel cells, it is imperative to develop competent fuel cell electrocatalysts composed of much fewer or no Pt-group metals. Recently, hydroxide exchange membrane fuel cells (HEMFCs) emerge as a promising alternative technology $y^{5,7-12}$, whose alkaline electrolytes enable the utilization of many inexpensive ORR electrocatalysts, some of which can compete the performance of Pt-based ORR electrocatalysts. Ironically, under alkaline condition, it is HOR, instead of ORR, becoming the challenging reaction, as even for Pt its HOR performance in alkaline HEMFCs is two orders of magnitude lower than that in acidic PEMFCs. Therefore, it is of fundamental and practical importance to develop highly competent and Earth-abundant electrocatalysts for improving hydrogen electrochemistry in both HER and HOR for the realization of hydrogen economy ${ }^{2,13}$.

Great research efforts have been devoted to the development of nonprecious HER electrocatalysts, including transition metal compounds, alloys, and molecular complexes ${ }^{14-19}$. Relatively less attention has been concentrated on the development of HOR electrocatalysts $8,9,20-23$. Since both HER and HOR involve the same critical intermediate species, adsorbed hydrogen $\left(\mathrm{H}^{*}\right)$ on the surface of an electrocatalyst, it is not surprising that hydrogen adsorption free energy $\left(\Delta \mathrm{G}_{\mathrm{H}^{*}}\right)$ has been widely adopted as a key descriptor in assessing the performance of diverse electrocatalyst candidates for HER and HOR $6,24,25$. The accumulated collection of experimental and theoretical results has unambiguously established volcano-type plots for HER/HOR activity versus $\Delta \mathrm{G}_{\mathrm{H}^{*}}$ on many electrocatalysts, indicating that the optimal HER/HOR performance will be achieved when $\Delta \mathrm{G}_{\mathrm{H}^{*}}$ is near $0 \mathrm{eV}^{3,26,27}$. Hence, great efforts have been focused on optimizing $\Delta \mathrm{G}_{\mathrm{H}^{*}}$ of diverse electrocatalysts through metal alloying $9,15,25$, composition variation $21,22,28$, crystal facet modification $^{17}$, defect introduction, size/dimension confinement ${ }^{29}$, and interface construction $7,8,20,30-36$. Despite the increasing efforts in advancing the HER and HOR activities of inexpensive electrocatalysts, most of them have not met the target performance for large-scale industrial applications. To the best of our knowledge, no catalytic systems ever reported focus on exploring the interfaces of first-row transition metals and their nitrides for hydrogen electrochemistry in aqueous media.
Herein, we demonstrate that purposely interfacing $\mathrm{Ni}$ and $\mathrm{Ni}_{3} \mathrm{~N}$ results in an electrocatalyst $\left(\mathrm{Ni}_{3} \mathrm{~N} / \mathrm{Ni}\right)$ with extraordinary activities for both HER and HOR. The rich $\mathrm{Ni}_{3} \mathrm{~N} / \mathrm{Ni}$ interfacial sites can be obtained by electrodeposition of Ni nanoparticles on current collectors such as $\mathrm{Ni}$ foam (NF) followed by thermal nitridation in ammonia $\left(\mathrm{Ni}_{3} \mathrm{~N} / \mathrm{Ni} / \mathrm{NF}\right)$. Through interface engineering, the resultant $\mathrm{Ni}_{3} \mathrm{~N} / \mathrm{Ni} / \mathrm{NF}$ demonstrates excellent HER apparent activity with nearly zero onset overpotential in alkaline and neutral electrolytes, requiring only 12 to $19 \mathrm{mV}$ overpotential to produce a current density of $-10 \mathrm{~mA} \mathrm{~cm}^{-2}$, which can rival the activity of $\mathrm{Pt} / \mathrm{C}$ catalyst loaded on NF under the present experimental conditions. Such exceptional electrocatalytic performance renders $\mathrm{Ni}_{3} \mathrm{~N} / \mathrm{Ni} / \mathrm{NF}$ the best among all the reported nonprecious HER electrocatalysts. Besides, the intrinsic specific activities (normalized by the real surface area or electrochemically active surface area) of $\mathrm{Ni}_{3} \mathrm{~N} / \mathrm{Ni} / \mathrm{NF}$ are also superior to those of $\mathrm{Pt} / \mathrm{C}$ catalysts loaded on NF for HER in neutral and alkaline electrolytes under similar experimental conditions within the scope of our investigation. Even more exciting is that $\mathrm{Ni}_{3} \mathrm{~N} / \mathrm{Ni} / \mathrm{NF}$ also shows superior $\mathrm{HOR}$ activity in alkaline medium $(0.1 \mathrm{M}$ $\mathrm{KOH}$ ) with a great tolerance to $\mathrm{CO}$ poisoning. Density functional theory calculations were conducted to shed light on the exceptional performance of $\mathrm{Ni}_{3} \mathrm{~N} / \mathrm{Ni} / \mathrm{NF}$. It was found that the interfacial sites between $\mathrm{Ni}_{3} \mathrm{~N}$ and $\mathrm{Ni}$ have very small values of $\Delta \mathrm{G}_{\mathrm{H}^{*}}$. The best hydrogen adsorption site on $\mathrm{Ni}_{3} \mathrm{~N} / \mathrm{Ni} / \mathrm{NF}$ exhibits a $\Delta \mathrm{G}_{\mathrm{H}^{*}}$ value of $0.01 \mathrm{eV}$, very close to the ideal amount of $0 \mathrm{eV}$. Furthermore, our computational results also imply that the existence of a $\mathrm{Ni}_{3} \mathrm{~N} / \mathrm{Ni}$ interface favors both the original adsorption and the subsequent dissociation of water on the catalyst surface, which is beneficial to HER (and arguably HOR as well) activity in alkaline and neutral electrolytes. Overall, $\mathrm{Ni}_{3} \mathrm{~N} /$ $\mathrm{Ni} / \mathrm{NF}$ represents an extremely active while still low-cost electrocatalyst with bifunctional activity for both HER and HOR. Our work also demonstrates that interfacing metals and nitrides is an effective strategy in creating inexpensive and high-performance catalysts of hydrogen electrochemistry, which deserves further attention for applications not only limited to water electrolyzers and fuel cells but also many other hydrogen-related reactions.

\section{Results}

Synthesis and characterization of interfacial $\mathrm{Ni}_{3} \mathrm{~N} / \mathrm{Ni}$. The $\mathrm{Ni}_{3} \mathrm{~N} / \mathrm{Ni}$ interfacial electrocatalysts were synthesized through the cathodic electrodeposition of porous $\mathrm{Ni}$ microspheres on common current collectors such as $\mathrm{Ni}$ foam (NF) or carbon foam (CF), followed by thermal nitridation in ammonia to create rich $\mathrm{Ni}_{3} \mathrm{~N} / \mathrm{Ni}$ interfacial sites. The nitridation temperature and duration were both optimized for $\mathrm{Ni}_{3} \mathrm{~N} / \mathrm{Ni} / \mathrm{NF}$. The nitridation temperature was varied from 200 to $400{ }^{\circ} \mathrm{C}$ and no $\mathrm{Ni}_{3} \mathrm{~N}$ was formed until the temperature reached $300^{\circ} \mathrm{C}$ (Supplementary Fig. 1). Further increasing the nitridation temperature led to the disappearance of the $\mathrm{Ni}_{3} \mathrm{~N}$ phase, most likely due to the low thermal stability of $\mathrm{Ni}_{3} \mathrm{~N}$ at high temperature $\left(>350^{\circ} \mathrm{C}\right)^{37,38}$. The nitridation duration was also varied at $300^{\circ} \mathrm{C}$ (Supplementary Fig. 2). On the basis of the weight increase after ammonia treatment, the weight percentage of $\mathrm{Ni}_{3} \mathrm{~N}$ in $\mathrm{Ni}_{3} \mathrm{~N} / \mathrm{Ni} / \mathrm{NF}$ increased from 8.67 to 44.66 wt.\% with the nitridation duration rising from 0.5 to $12 \mathrm{~h}$, indicating the increased coverage of $\mathrm{Ni}_{3} \mathrm{~N}$ (Supplementary Fig. 3). The $\mathrm{Ni}_{3} \mathrm{~N} / \mathrm{Ni} / \mathrm{NF}$ synthesized at $300{ }^{\circ} \mathrm{C}$ for $6 \mathrm{~h}$ with the weight percentage of $\mathrm{Ni}_{3} \mathrm{~N}$ of 41.82 wt.\% exhibits the highest HER activity, while longer duration resulted in decreased HER activity (see Discussion).

The scanning electron microscopy (SEM) images in Fig. 1a illustrate that $\mathrm{Ni}_{3} \mathrm{~N} / \mathrm{Ni} / \mathrm{NF}$ prepared at $300{ }^{\circ} \mathrm{C}$ for $6 \mathrm{~h}$ possessed three-dimensional (3D) macroporous ligament network structure 
a
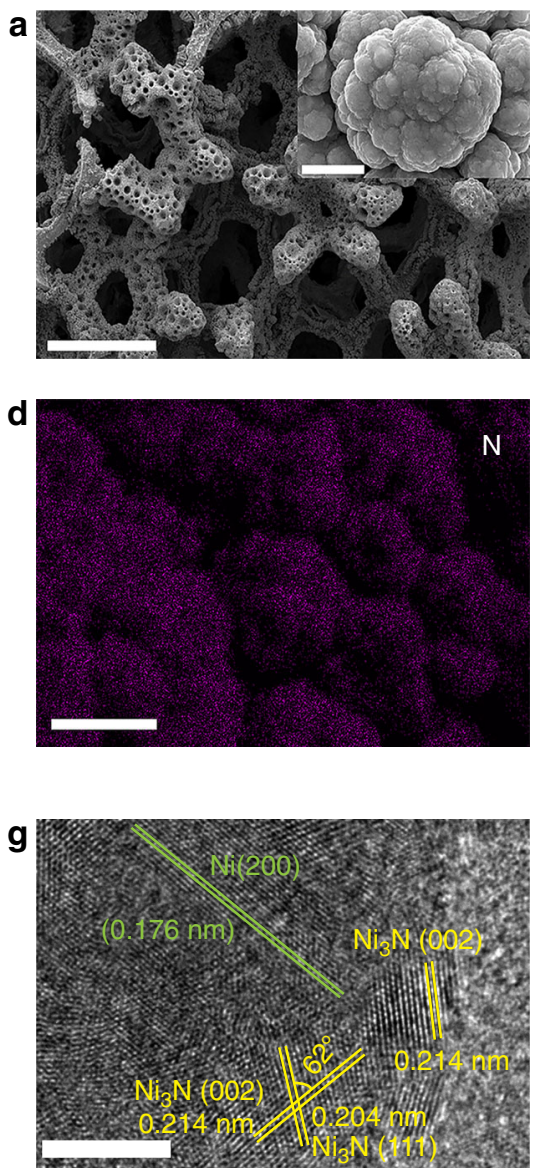

b
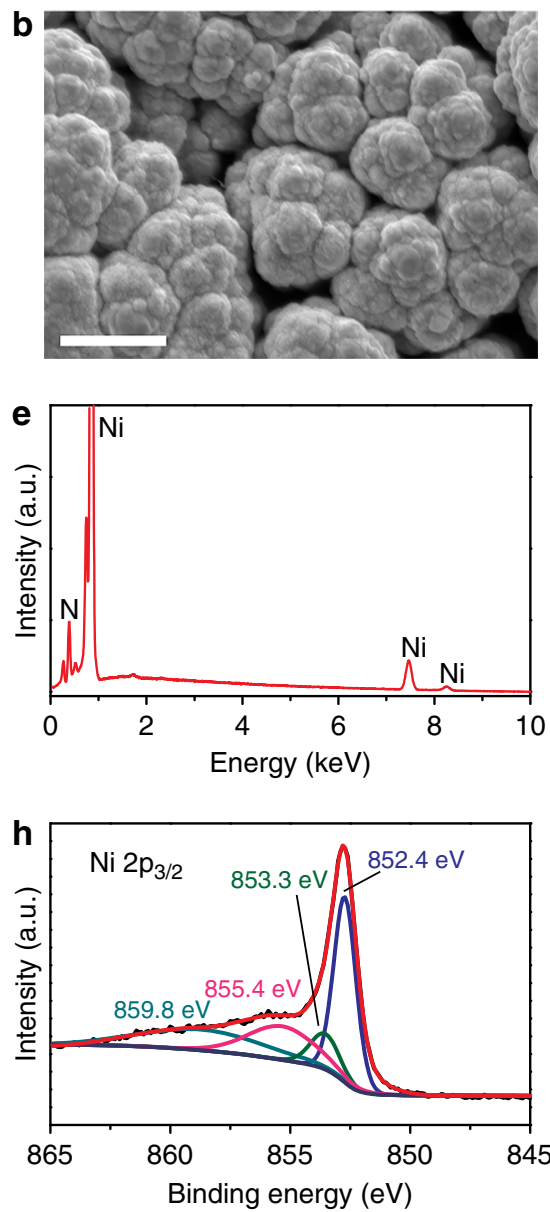

c
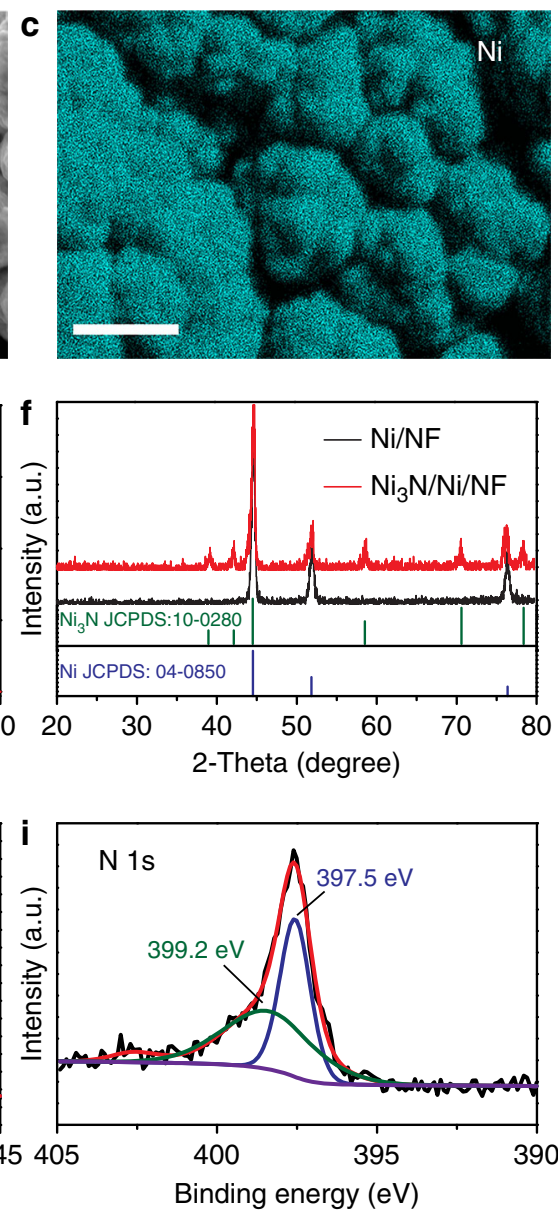

Fig. 1 Characterization of $\mathrm{Ni}_{3} \mathrm{~N} / \mathrm{Ni}$ interfacial electrocatalysts. $\mathbf{a}, \mathbf{b} \mathrm{SEM}$ images of $\mathrm{Ni}_{3} \mathrm{~N} / \mathrm{Ni} / \mathrm{NF}$ at different magnifications. Elemental mapping images of $\mathrm{Ni}$ (c) and $\mathrm{N}$ (d). Scale bars, $500 \mu \mathrm{m}$ (a); $3 \mu \mathrm{m}$ inset of $\mathbf{a} ; 10 \mu \mathrm{m}$ (b-d). e EDX spectrum of $\mathrm{Ni}_{3} \mathrm{~N} / \mathrm{Ni} / \mathrm{NF}$. $\mathbf{f}$ XRD patterns of Ni $\mathrm{N} / \mathrm{Ni} / \mathrm{NF}$ and Ni/NF. $\mathbf{g} \mathrm{HRTEM}$ image of $\mathrm{Ni}_{3} \mathrm{~N} / \mathrm{Ni}$ interface. Scale bar, $5 \mathrm{~nm}(\mathbf{g})$. h, i XPS spectra of $\mathrm{Ni}_{2} 2 \mathrm{p}_{3 / 2}(\mathbf{h})$ and $\mathrm{N} 1 \mathrm{~s}(\mathbf{i})$

with numerous stacked coarse particles over the skeleton surface, which is inherited from the electrodeposited Ni/NF sample yet in sharp contrast to the smooth surface of pristine $\mathrm{Ni}$ foams (Supplementary Fig. 4). The elemental mapping images of $\mathrm{Ni}_{3} \mathrm{~N} /$ $\mathrm{Ni} / \mathrm{NF}$ show that $\mathrm{Ni}$ and $\mathrm{N}$ are uniformly distributed and the energy dispersive $\mathrm{X}$-ray (EDX) spectrum confirms the major composition of $\mathrm{Ni}$ and $\mathrm{N}$ in $\mathrm{Ni}_{3} \mathrm{~N} / \mathrm{Ni} / \mathrm{NF}$ (Fig. $\mathrm{lb}-\mathrm{e}$ ). The $\mathrm{X}$-ray diffraction (XRD) patterns (Fig. 1f) suggest that after nitridation new peaks attributed to hexagonal $\mathrm{Ni}_{3} \mathrm{~N}$ (JCPDS card No. 100280) appeared while the major composition of $\mathrm{Ni}_{3} \mathrm{Ni} / \mathrm{Ni} / \mathrm{NF}$ remained as the cubic Ni phase (JCPDS card No. 04-0850) ${ }^{38}$. The high-resolution transmission electron microscopy (HRTEM) image of the $\mathrm{Ni}_{3} \mathrm{~N} / \mathrm{Ni}$ interfacial electrocatalyst clearly shows the interface between hexagonal $\mathrm{Ni}_{3} \mathrm{~N}$ and cubic Ni (Fig. 1g). The well-resolved lattice fringes with inter-planar spacing of 0.204 and $0.214 \mathrm{~nm}$ can be unambiguously assigned to the (111) and (002) crystal planes of hexagonal $\mathrm{Ni}_{3} \mathrm{~N}$ with an intersection angle of $62^{\circ 39,40}$, in agreement with the XRD results. The unique lattice fringes with inter-planar distance of $0.176 \mathrm{~nm}$ correspond to the (200) crystal plane of cubic Ni. Moreover, the elemental mapping results of $\mathrm{N}$ and $\mathrm{Ni}$ (Supplementary Fig. 5) demonstrate that $\mathrm{Ni}$ is homogeneously distributed, while $\mathrm{N}$ is sporadically located. The HRTEM and elemental mapping results corroborate the successful formation of rich $\mathrm{Ni}_{3} \mathrm{~N} / \mathrm{Ni}$ interfaces. The surface elements and their valence states in $\mathrm{Ni}_{3} \mathrm{~N} / \mathrm{Ni} / \mathrm{NF}$ were further probed by $\mathrm{X}$ ray photoelectron spectroscopy (XPS). As shown in Fig. 1h, the high-resolution $\mathrm{Ni} 2 \mathrm{p}_{3 / 2}$ spectrum can be deconvoluted to features with maxima at 852.4 and $853.3 \mathrm{eV}$, which are assignable to metallic $\mathrm{Ni}$ and $\mathrm{Ni}(\mathrm{I})$ of $\mathrm{Ni}_{3} \mathrm{~N}$, respectively ${ }^{41-44}$. A small peak at $855.4 \mathrm{eV}$ corresponds to the oxidized $\mathrm{Ni}$ species likely due to adventitious surface oxidation; while the satellite peak at $859.8 \mathrm{eV}$ is attributed to the shake-up excitation of the high-spin nickel ions $^{42}$. The N $1 \mathrm{~s}$ XPS spectrum in Fig. $1 \mathrm{i}$ can be simulated by the combination of two features at 397.5 and $399.2 \mathrm{eV}$, ascribed to $\mathrm{N}$ species of $\mathrm{Ni}_{3} \mathrm{~N}$ and $\mathrm{NH}$ moieties, respectively, in which the latter likely resulted from the incomplete reaction with $\mathrm{NH}_{3}{ }^{42,45,46}$. Due to the partial transformation of surface $\mathrm{Ni}$ to $\mathrm{Ni}_{3} \mathrm{~N}$, the collective characterization results discussed above suggest that $\mathrm{Ni}_{3} \mathrm{~N} / \mathrm{Ni} / \mathrm{NF}$ inevitably possesses rich interfacial sites between $\mathrm{Ni}$ and $\mathrm{Ni}_{3} \mathrm{~N}$.

Electrocatalytic $\mathbf{H}_{2}$ evolution. The electrocatalytic performance of $\mathrm{Ni}_{3} \mathrm{~N} / \mathrm{Ni} / \mathrm{NF}$ towards $\mathrm{HER}$ was investigated in $\mathrm{H}_{2}$-saturated electrolytes of 1.0 M potassium phosphate (KPi) buffer ( $\mathrm{pH} 7.17$ ) and $1.0 \mathrm{M} \mathrm{KOH}(\mathrm{pH} 13.80)$. All potentials reported herein are referenced to the reversible hydrogen electrode (RHE) and the current densities were calculated on the basis of both the geometric areas and the real surface areas of electrodes. The effects of nitridation temperature and duration of $\mathrm{Ni}_{3} \mathrm{~N} / \mathrm{Ni} / \mathrm{NF}$ on the electrocatalytic HER activity were first studied. As shown in Supplementary Figs. $6-7$, the $\mathrm{Ni}_{3} \mathrm{~N} / \mathrm{Ni} / \mathrm{NF}$ synthesized at $300{ }^{\circ} \mathrm{C}$ for $6 \mathrm{~h}$ possessed the best HER activity in all electrolytes, highlighting the importance in obtaining the appropriate amount of $\mathrm{Ni}_{3} \mathrm{~N} / \mathrm{Ni}$ interfacial sites for optimal HER performance. Therefore, all the following studies were conducted on $\mathrm{Ni}_{3} \mathrm{~N} / \mathrm{Ni} / \mathrm{NF}$ prepared at $300^{\circ} \mathrm{C}$ for $6 \mathrm{~h}$ unless noted otherwise. 
a

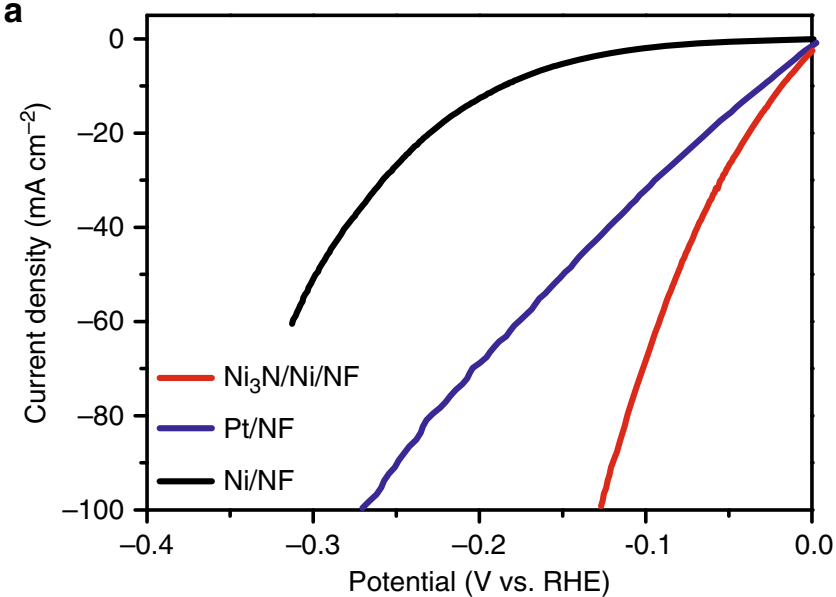

C

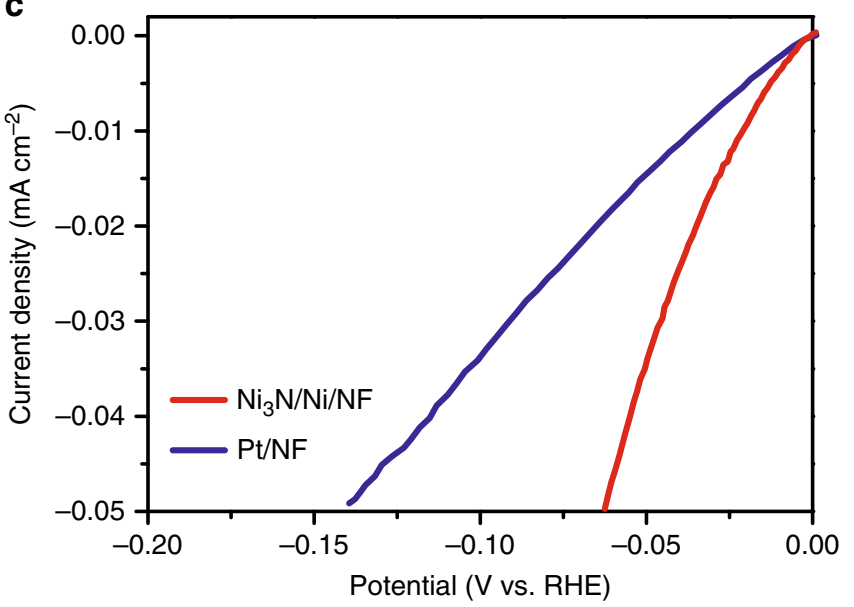

b

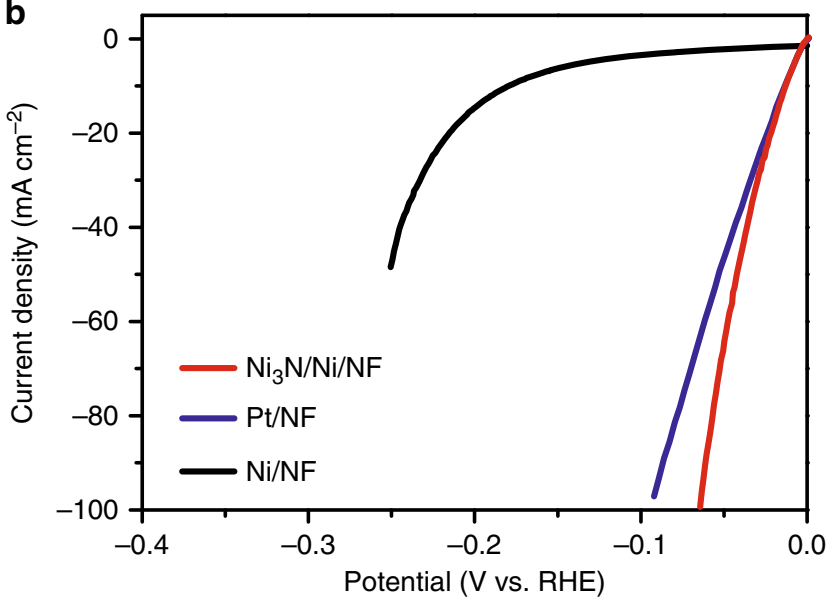

d

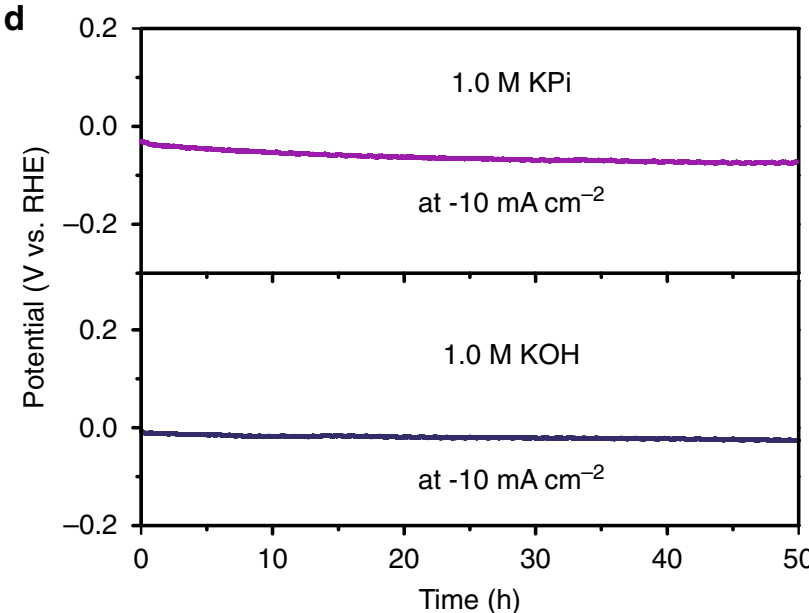

Fig. 2 The electrocatalytic HER performance in neutral and alkaline solutions. a, b Linear sweep voltammetry (LSV) curves of $\mathrm{Ni} i_{3} \mathrm{~N} / \mathrm{Ni} / \mathrm{NF}, \mathrm{Ni} / \mathrm{NF}$, and optimized Pt/NF (Pt/C: $2.5 \mathrm{mg} \mathrm{cm}^{-2}$ ) for HER in $1.0 \mathrm{M}$ potassium phosphate (KPi) buffer (a) and $1.0 \mathrm{M} \mathrm{KOH}$ (b) with the current density normalized by the geometric electrode area. c LSV curves of $\mathrm{Ni}_{3} \mathrm{~N} / \mathrm{Ni} / \mathrm{NF}$ and Pt/NF for HER in $1.0 \mathrm{M} \mathrm{KOH}$ with the current density normalized by their respective BET surface areas. All LSV curves are iR-corrected. $\mathbf{d}$ Chronopotentiometry curves of $\mathrm{Ni}_{3} \mathrm{~N} / \mathrm{Ni} / \mathrm{NF}$ collected at $-10 \mathrm{~mA} \mathrm{~cm}^{-2}$ normalized by the geometric electrode area in $1.0 \mathrm{M} \mathrm{KPi}$ (top) and $1.0 \mathrm{M} \mathrm{KOH}$ (bottom) without iR correction

For comparison, Pt/C (20 wt.\%) powder loaded on the sametype nickel foam was included as a control sample (Pt/NF). The loading amount of $\mathrm{Pt} / \mathrm{C}\left(2.5 \mathrm{mg} \mathrm{cm}^{-2}\right)$ was optimized to achieve the best electrocatalytic HER activity under each $\mathrm{pH}$ condition (Supplementary Figs. 8-9). The iR-corrected linear sweep voltammetry (LSV) curves of $\mathrm{Ni}_{3} \mathrm{~N} / \mathrm{Ni} / \mathrm{NF}, \mathrm{Ni} / \mathrm{NF}$, and $\mathrm{Pt} / \mathrm{NF}$ for $\mathrm{H}_{2}$ evolution at different $\mathrm{pH}$ are plotted in Fig. 2a, b. Under neutral and alkaline conditions, because of the lack of free protons, water adsorption and dissociation generally take place prior to $\mathrm{H}_{2}$ evolution $2,5,30,47$. To our delight, $\mathrm{Ni}_{3} \mathrm{~N} / \mathrm{Ni} / \mathrm{NF}$ exhibited extraordinary HER performance with catalytic onset potentials at $\sim 0 \mathrm{~V}$ vs. RHE and required an overpotential of only 19 and $12 \mathrm{mV}$ to deliver a current density of $-10 \mathrm{~mA} \mathrm{~cm}^{-2}$ in 1.0 $\mathrm{M} \mathrm{KPi}$ buffer and 1.0 M KOH, respectively. In 1.0 M KPi, in order to produce an industrially meaningful current density like -100 $\mathrm{mA} \mathrm{cm}{ }^{-2}, \mathrm{Ni}_{3} \mathrm{~N} / \mathrm{Ni} / \mathrm{NF}$ only needed an overpotential of $126 \mathrm{mV}$. However, an overpotential of $272 \mathrm{mV}$ was required for $\mathrm{Pt} / \mathrm{NF}$ to deliver the same HER current. Without nitridation, the parent $\mathrm{Ni}$ / NF showed rather mediocre HER activity. The drastic difference in their HER activities of $\mathrm{Ni}_{3} \mathrm{~N} / \mathrm{Ni} / \mathrm{NF}$ and $\mathrm{Ni} / \mathrm{NF}$ unequivocally proves the critical role of the $\mathrm{Ni}_{3} \mathrm{~N} / \mathrm{Ni}$ interfaces formed during nitridation in catalyzing $\mathrm{H}_{2}$ production, as these two electrodes have similar morphology. The best HER performance of $\mathrm{Ni}_{3} \mathrm{~N} /$ $\mathrm{Ni} / \mathrm{NF}$ was achieved in 1.0 M KOH, wherein an overpotential of merely $64 \mathrm{mV}$ was needed to produce $-100 \mathrm{~mA} \mathrm{~cm}^{-2}$, saving at least $31 \mathrm{mV}$ of voltage input relative to that on $\mathrm{Pt} / \mathrm{NF}$. The charge transfer resistance of $\mathrm{Ni}_{3} \mathrm{~N} / \mathrm{Ni} / \mathrm{NF}$ was also much smaller than that of Ni/NF under the same conditions (Supplementary Figs. 10-11).

In order to assess the intrinsic specific activities of $\mathrm{Ni}_{3} \mathrm{~N} / \mathrm{Ni} / \mathrm{NF}$ and $\mathrm{Pt} / \mathrm{NF}$, their electrocatalytic activities were normalized by the Brunauer-Emmett-Teller (BET) surface area measured by $\mathrm{N}_{2}$ adsorption-desorption ${ }^{48}$ and the electrochemically active surface area (ECSA) measured by the double layer capacitance method on the basis of cyclic voltammetry in a nonaqueous aprotic $\mathrm{KPF}_{6}-\mathrm{CH}_{3} \mathrm{CN}$ electrolyte (Fig. 2c, Supplementary Figs. 12-16 and Tables $1-2)^{49}$. Apparently, $\mathrm{Ni}_{3} \mathrm{~N} / \mathrm{Ni} / \mathrm{NF}$ showed higher specific activity than $\mathrm{Pt} / \mathrm{NF}$ for HER in alkaline and neutral electrolytes under similar experimental measurement conditions. The Tafel plots of $\mathrm{Ni}_{3} \mathrm{~N} / \mathrm{Ni} / \mathrm{NF}, \mathrm{Pt} / \mathrm{NF}$, and $\mathrm{Ni} / \mathrm{NF}$ derived from their respective polarization curves in $1.0 \mathrm{M} \mathrm{KOH}$ presented overpotential-dependent Tafel slopes (Supplementary Fig. 17). The findings of variable Tafel slopes were reported for many HER electrocatalysts including $\mathrm{Co}_{0.6} \mathrm{Mo}_{1.4} \mathrm{~N}_{2}{ }^{45}, \mathrm{Pt}^{50-52}, \mathrm{Ni}-\mathrm{Mo}-\mathrm{Cd}^{53}$, $\mathrm{Ni}_{2} \mathrm{P}^{54,55}, \mathrm{MoP}^{56}$, and $\mathrm{FeP} / \mathrm{Ni}_{2} \mathrm{P}^{57}$ under different $\mathrm{pH}$ conditions. This phenomenon could be attributed to many factors, such as back reaction at low overpotentials, mass transport together with the blocking effect of produced $\mathrm{H}_{2}$ bubbles at high overpotentials, 
formation of a large number of $\mathrm{N}-\mathrm{H}$ moieties, and the dependence of adsorbed hydrogen intermediate on overpotential $45,50,58$. Therefore, it is difficult to ascertain the rate determining step(s) and kinetic mechanism of $\mathrm{Ni}_{3} \mathrm{~N} / \mathrm{Ni} / \mathrm{NF}$ for HER from its potential-dependent Tafel slopes. Future work will aim to elucidate the catalytic mechanism of $\mathrm{Ni}_{3} \mathrm{~N} / \mathrm{Ni}$ with more sophisticated electrochemical techniques ${ }^{47,59}$.

The exciting HER activity of $\mathrm{Ni}_{3} \mathrm{~N} / \mathrm{Ni} / \mathrm{NF}$ prompted us to further evaluate its durability for long-term $\mathrm{H}_{2}$ production through repetitive cyclic voltammetry $(\mathrm{CV})$ and chronopotentiometry experiments. After $5000 \mathrm{CV}$ cycles in $1.0 \mathrm{M} \mathrm{KPi}$ and 10,000 $\mathrm{CV}$ cycles in $1.0 \mathrm{M} \mathrm{KOH}, \mathrm{Ni}_{3} \mathrm{~N} / \mathrm{Ni} / \mathrm{NF}$ only showed a slight overpotential increase by ca. $9 \mathrm{mV}$ for delivering $-100 \mathrm{~mA} \mathrm{~cm}^{-2}$ under both neutral and alkaline conditions (Supplementary Figs. 18-19). As plotted in Fig. $2 \mathrm{~d}, \mathrm{Ni}_{3} \mathrm{~N} / \mathrm{Ni} / \mathrm{NF}$ also demonstrated very stable potential requirement over $50 \mathrm{~h}$ of galvanostatic electrolysis at $-10 \mathrm{~mA} \mathrm{~cm}^{-2}$ in both neutral and alkaline electrolytes. It could also produce a high current density of $-100 \mathrm{~mA} \mathrm{~cm}^{-2}$ over $10 \mathrm{~h}$ with negligible degradation in $1.0 \mathrm{M}$ $\mathrm{KOH}$ (Supplementary Fig. 20). Post-electrolysis characterization confirmed that $\mathrm{Ni}_{3} \mathrm{~N} / \mathrm{Ni} / \mathrm{NF}$ retained its original morphology and exhibited negligible changes of morphology, crystallinity, and composition after extended HER electrolysis (Supplementary Figs. 21-23), highlighting its outstanding structural robustness and mechanical stability. The produced $\mathrm{H}_{2}$ amount well matched the theoretically calculated quantity (Supplementary Fig. 24) assuming that all the passed charge was utilized to generate $\mathrm{H}_{2}$, implying a Faradaic efficiency close to $100 \%$.

In order to reveal the roles of $\mathrm{Ni}$ foam and $\mathrm{Ni} / \mathrm{NF}$, thermal nitridation was also conducted on either carbon foam (CF) with pre-electrodeposited $\mathrm{Ni}$ microparticles or bare $\mathrm{Ni}$ foam to obtain two control samples of $\mathrm{Ni}_{3} \mathrm{~N} / \mathrm{Ni} / \mathrm{CF}$ and $\mathrm{Ni}_{3} \mathrm{~N} / \mathrm{NF}$, respectively. The comprehensive characterization of $\mathrm{Ni}_{3} \mathrm{~N} / \mathrm{Ni} / \mathrm{CF}$ confirmed the presence of $\mathrm{Ni}_{3} \mathrm{~N} / \mathrm{Ni}$ interfaces over $\mathrm{CF}$ with the composition, morphology, and crystallinity similar to those of $\mathrm{Ni}_{3} \mathrm{~N} / \mathrm{Ni} / \mathrm{NF}$ (Supplementary Figs. 25-27). Electrochemical studies revealed that $\mathrm{Ni}_{3} \mathrm{~N} / \mathrm{Ni} / \mathrm{CF}$ exhibited nearly identical HER activity as $\mathrm{Ni}_{3} \mathrm{~N} /$ $\mathrm{Ni} / \mathrm{NF}$ (Supplementary Figs. 28-29), demonstrating that the $\mathrm{Ni}_{3} \mathrm{~N} / \mathrm{Ni}$ interfacial sites are the real active sites of HER and their activities are independent of the electrode support. In sharp contrast, $\mathrm{Ni}_{3} \mathrm{~N} / \mathrm{NF}$ has smooth surface (Supplementary Fig. 30) and shows much lower electrocatalytic HER activities in alkaline and neutral solutions (Supplementary Figs. 31-32), indicating the advantages of using rough and porous $\mathrm{Ni} / \mathrm{NF}$ for thermal nitridation to obtain $\mathrm{Ni}_{3} \mathrm{~N} / \mathrm{Ni} / \mathrm{NF}$.

Overall, the low cost, exceptional activity, and robust durability of $\mathrm{Ni}_{3} \mathrm{~N} / \mathrm{Ni} / \mathrm{NF}$ (and $\mathrm{Ni}_{3} \mathrm{~N} / \mathrm{Ni} / \mathrm{CF}$ ) render it a promising electrocatalyst for sustainable $\mathrm{H}_{2}$ production from water, ranking it the best among most of the reported nonprecious HER electrocatalysts (Supplementary Table 3 \& Fig. 33) ${ }^{29,60,61}$, including nanostructured $\mathrm{Ni}_{3} \mathrm{~N}, \mathrm{Ni}_{3} \mathrm{~N} / \mathrm{Ni}(\mathrm{OH})_{2}$, and $\mathrm{Pt} / \mathrm{Ni}_{3} \mathrm{~N}^{42,62-64}$.

Theoretical computations. In order to shed light on the superior activity of $\mathrm{Ni}_{3} \mathrm{~N} / \mathrm{Ni} / \mathrm{NF}$ as a HER electrocatalyst, DFT calculations were conducted on model systems. We modeled the $\mathrm{Ni}_{3} \mathrm{~N}$ and blank Ni control samples by their lowest energy-surfaces of bulk $\mathrm{Ni}_{3} \mathrm{~N}(001)$ and $\mathrm{Ni}(111)$, respectively. In order to model the interfacing structure of $\mathrm{Ni}_{3} \mathrm{~N} / \mathrm{Ni}$, we reasoned that an appropriate structure was a few layers of nitrogen-terminated $\mathrm{Ni}_{3} \mathrm{~N}$ located on the $\mathrm{Ni}(111)$ surface. As proposed by Nørskov et al., the adsorption energy of hydrogen has been widely employed as a descriptor for predicting the HER performance of many electrocatalysts ${ }^{3,27}$. As shown in Fig. 3a and Supplementary Figs. 34-36, hydrogen atoms are preferred to adsorb along the interface between $\mathrm{Ni}_{3} \mathrm{~N}$ and $\mathrm{Ni}$ in $\mathrm{Ni}_{3} \mathrm{~N} / \mathrm{Ni}$. In fact, two interfacial sites $\left(\mathrm{Ni}_{3} \mathrm{~N} / \mathrm{Ni} \_\mathrm{N}\right.$ and
$\mathrm{Ni}_{3} \mathrm{~N} / \mathrm{Ni}$ hollow) were identified with very weak hydrogen adsorption energies (Supplementary Table 4). The resulting free energy changes $\left(\Delta \mathrm{G}_{\mathrm{H}^{*}}\right)$ of hydrogen adsorption at these two positions of $\mathrm{Ni}_{3} \mathrm{~N} / \mathrm{Ni}$ (Fig. 3b) were calculated to be 0.01 and $-0.07 \mathrm{eV}$, which are very close to $0 \mathrm{eV}^{27}$. In contrast, pure $\mathrm{Ni}$ exhibits very strong hydrogen affinity with calculated $\Delta \mathrm{G}_{\mathrm{H}^{*}}$ close to $-0.30 \mathrm{eV}$ (Fig. $3 \mathrm{~b}$ and Supplementary Figs. 37-38). Even though there exists one site on $\mathrm{Ni}_{3} \mathrm{~N}$ which has a $\Delta \mathrm{G}_{\mathrm{H}^{*}}$ of $0.01 \mathrm{eV}$, there is another site on $\mathrm{Ni}_{3} \mathrm{~N}$ showing very strong hydrogen binding affinity $\left(\Delta \mathrm{G}_{\mathrm{H}^{*}}=-0.57 \mathrm{eV}\right)$, which would not be beneficial towards efficient hydrogen electrochemistry (Fig. $3 \mathrm{~b}$ and Supplementary Figs. 39-40).

In order to better understand the HER activity trend among $\mathrm{Ni}_{3} \mathrm{~N} / \mathrm{Ni}, \mathrm{Ni}_{3} \mathrm{~N}$, and $\mathrm{Ni}$ under neutral and alkaline conditions which are lack of free protons, we sought to investigate the adsorption and dissociation of water on catalyst surface, which was believed to shed more lights on their hydrogen electrochemistry. The computed water adsorption energies on $\mathrm{Ni}_{3} \mathrm{~N} / \mathrm{Ni}$, $\mathrm{Ni}_{3} \mathrm{~N}$, and $\mathrm{Ni}$ are compared in Fig. $3 \mathrm{c}$ and their corresponding adsorption configurations are shown in Supplementary Fig. 41. It is apparent that $\mathrm{Ni}_{3} \mathrm{~N} / \mathrm{Ni}$ and $\mathrm{Ni}$ possess similar water adsorption energies, much higher than that on $\mathrm{Ni}_{3} \mathrm{~N}$. Based on the optimal water adsorption structure on $\mathrm{Ni}_{3} \mathrm{~N} / \mathrm{Ni}$, one can conclude that indeed the adsorbed water prefers to reside along the interface between $\mathrm{Ni}_{3} \mathrm{~N}$ and $\mathrm{Ni}$ with one hydrogen atom pointing towards the edge $\mathrm{N}$ in $\mathrm{Ni}_{3} \mathrm{~N}$, probably due to hydrogen bond interaction. Such interaction also facilitates the subsequent water dissociation on $\mathrm{Ni}_{3} \mathrm{~N} / \mathrm{Ni}$. Figure $3 \mathrm{~d}$ and Supplementary Figs. $42-44$ present the comparison of the activation energy barrier of water dissociation on $\mathrm{Ni}_{3} \mathrm{~N} / \mathrm{Ni}, \mathrm{Ni}_{3} \mathrm{~N}$, and $\mathrm{Ni}$. As expected, $\mathrm{Ni}_{3} \mathrm{~N} / \mathrm{Ni}$ shows the lowest energy barrier $(0.50 \mathrm{eV})$ for water dissociation, nearly $0.08 \mathrm{eV}$ smaller than that on $\mathrm{Ni}_{3} \mathrm{~N}$ and $0.42 \mathrm{eV}$ lower than that on $\mathrm{Ni}$. The transition state structures of water dissociation on $\mathrm{Ni}, \mathrm{Ni}_{3} \mathrm{~N}$, and $\mathrm{Ni}_{3} \mathrm{~N} / \mathrm{Ni}$ are included in Fig. 3e. Collectively, these computational results further corroborate our hypothesis that the interfacial sites present on the surface of $\mathrm{Ni}_{3} \mathrm{~N} / \mathrm{Ni}$ indeed exhibit appropriate binding affinities towards hydrogen and water, and can also facilitate water dissociation, consistent with our experimentally obtained HER performance of $\mathrm{Ni}_{3} \mathrm{~N} / \mathrm{Ni}$ from neutral to alkaline conditions.

Electrocatalytic $\mathbf{H}_{2}$ oxidation. The nearly zero catalytic onset potential for HER and very small free energy change of hydrogen adsorption of $\mathrm{Ni}_{3} \mathrm{~N} / \mathrm{Ni} / \mathrm{NF}$ granted us confidence to believe that $\mathrm{Ni}_{3} / \mathrm{Ni} / \mathrm{NF}$ could act as an excellent electrocatalyst for $\mathrm{H}_{2}$ oxidation as well. Currently, it remains a critical challenge in developing inexpensive HOR electrocatalysts in alkaline electrolytes for the widespread employment of HEMFCs ${ }^{6,9,65-67}$. Due to the monolithic nature of the $\mathrm{Ni}_{3} \mathrm{~N} / \mathrm{Ni} / \mathrm{NF}$ electrode, its $\mathrm{HOR}$ performance was measured in $\mathrm{H}_{2}$-saturated $0.1 \mathrm{M} \mathrm{KOH}$ with continuous $\mathrm{H}_{2}$ bubbling to mimic the HEMFC condition. For comparison, $\mathrm{Pt} / \mathrm{C}$ was also loaded on NF and optimized $(1.5 \mathrm{mg}$ $\mathrm{cm}^{-2}$ ) to achieve the best HOR activity under the similar conditions (Supplementary Fig. 45). The polarization curves of $\mathrm{Ni}_{3} \mathrm{~N} /$ $\mathrm{Ni} / \mathrm{NF}$ collected between 0 and $0.1 \mathrm{~V}$ vs. RHE in $\mathrm{H}_{2}$ and $\mathrm{Ar}$ saturated $0.1 \mathrm{M} \mathrm{KOH}$ are plotted in Supplementary Fig. 46. In contrast to the negligible capacitance current obtained in the Arsaturated electrolyte, $\mathrm{Ni}_{3} \mathrm{~N} / \mathrm{Ni} / \mathrm{NF}$ showed appreciable anodic current beyond $0 \mathrm{~V}$ vs. $\mathrm{RHE}$ upon $\mathrm{H}_{2}$ saturation, implying the anodic current was due to $\mathrm{H}_{2}$ oxidation. In fact, the HOR catalytic current of $\mathrm{Ni}_{3} \mathrm{~N} / \mathrm{Ni} / \mathrm{NF}$ took off at $0 \mathrm{~V}$ vs. RHE, very close to that on $\mathrm{Pt} / \mathrm{NF}$, and surpassed the latter's at increasing applied potential (Fig. 4a). At $0.09 \mathrm{~V}$ vs. $\mathrm{RHE}, \mathrm{Ni}_{3} \mathrm{~N} / \mathrm{Ni} / \mathrm{NF}$ achieved a current density of $6.95 \mathrm{~mA} \mathrm{~cm}^{-2}$, higher than that of Pt/NF $(5.25$ $\mathrm{mA} \mathrm{cm}^{-2}$ ), whereas $\mathrm{Ni} / \mathrm{NF}$ only exhibited a current density of 
a

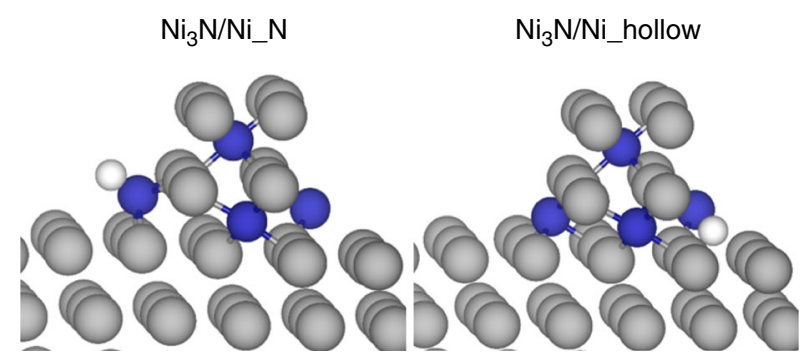

b

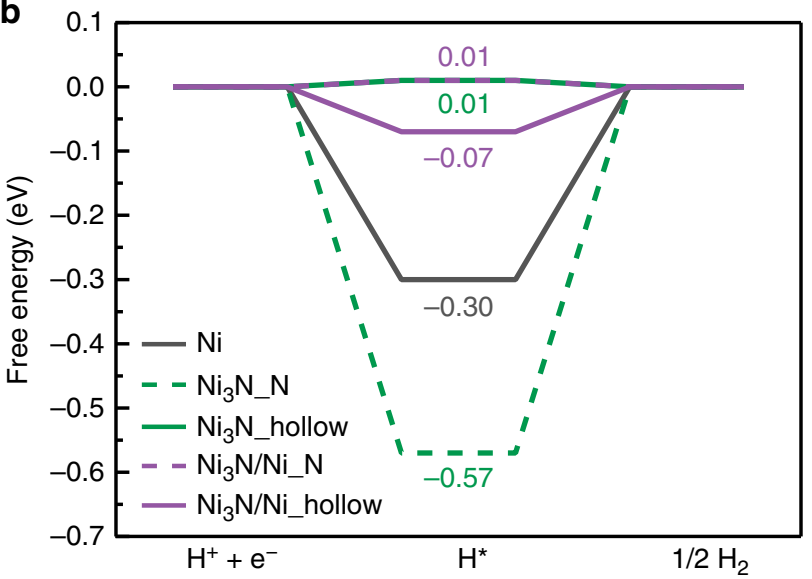

d

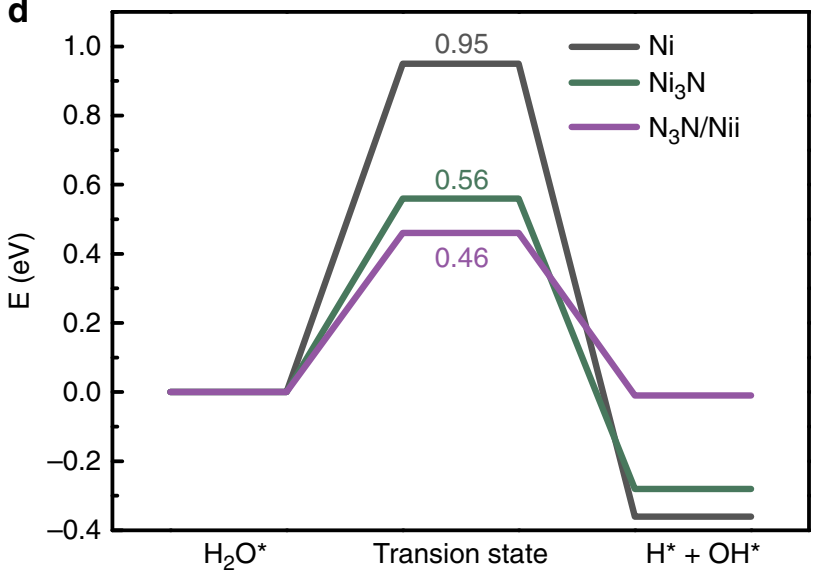

e
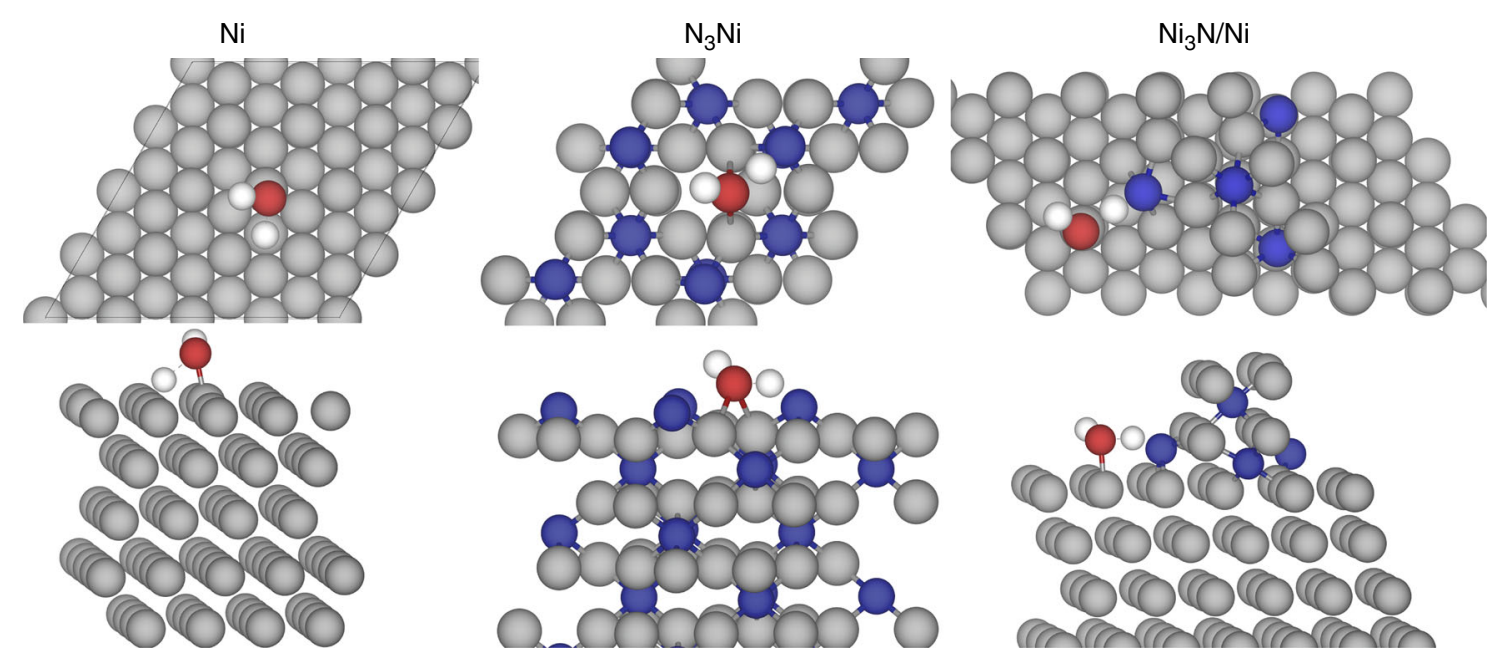

Fig. 3 DFT calculation results. a DFT-optimized structures of hydrogen adsorption at two interfacial sites of $\mathrm{Ni}_{3} \mathrm{~N} / \mathrm{Ni}$. $\mathbf{b}$ Hydrogen adsorption free energy $\left(\Delta \mathrm{G}_{\mathrm{H}^{*}}\right)$ on $\mathrm{Ni}, \mathrm{Ni}_{3} \mathrm{~N}$, and $\mathrm{Ni} \mathrm{i}_{3} \mathrm{~N} / \mathrm{Ni}$. c Adsorption energy of water on $\mathrm{Ni}, \mathrm{Ni}_{3} \mathrm{~N}$, and $\mathrm{Ni}{ }_{3} \mathrm{~N} / \mathrm{Ni}$. $\mathbf{d}$ Energy barrier for water dissociation on $\mathrm{Ni}$, $\mathrm{Ni} \mathrm{N}_{3} \mathrm{~N}$, and $\mathrm{Ni}{ }_{3} \mathrm{~N} / \mathrm{Ni}$. e Transition state structures for water dissociation over $\mathrm{Ni}_{1} \mathrm{Ni}_{3} \mathrm{~N}$, and $\mathrm{Ni}_{3} \mathrm{~N} / \mathrm{Ni}$, showing both the top view (top of e) and side view (bottom of e) of each structure. Color code: Ni: gray; N: blue; O: red; H: white

merely $0.34 \mathrm{~mA} \mathrm{~cm}^{-2}$. The exchange current density was estimated from the micro-polarization region within a small potential window from -20 to $20 \mathrm{mV}$ vs. RHE (Supplementary Fig. 47). Both $\mathrm{Ni}_{3} \mathrm{~N} / \mathrm{Ni} / \mathrm{NF}$ and $\mathrm{Pt} / \mathrm{NF}$ showed electrocatalytic HER and HOR activities starting at nearly zero overpotential in $0.1 \mathrm{M} \mathrm{KOH}$. The calculated exchange current density of $\mathrm{Ni}_{3} \mathrm{~N} / \mathrm{Ni} /$ $\mathrm{NF}$ was $3.08 \mathrm{~mA} \mathrm{~cm}^{-2}$, which was 1.4 and 17.6 times that of Pt/
$\mathrm{Ni}$ and $\mathrm{Ni} / \mathrm{NF}$, respectively. It was found that $\mathrm{Ni}_{3} \mathrm{~N} / \mathrm{Ni} / \mathrm{NF}$ showed higher specific activity than Pt/NF for HOR under similar experimental conditions, even if the current densities were normalized by their respective BET surface areas and/or ECSAs (Supplementary Figs. 48-49). The stability of $\mathrm{Ni}_{3} \mathrm{~N} / \mathrm{Ni} / \mathrm{NF}$ for long-term $\mathrm{H}_{2}$ oxidation was assessed via chronoamperometry at $0.09 \mathrm{~V}$ vs. $\mathrm{RHE}$ in $\mathrm{H}_{2}$-saturated $0.1 \mathrm{M} \mathrm{KOH}$ and compared with 

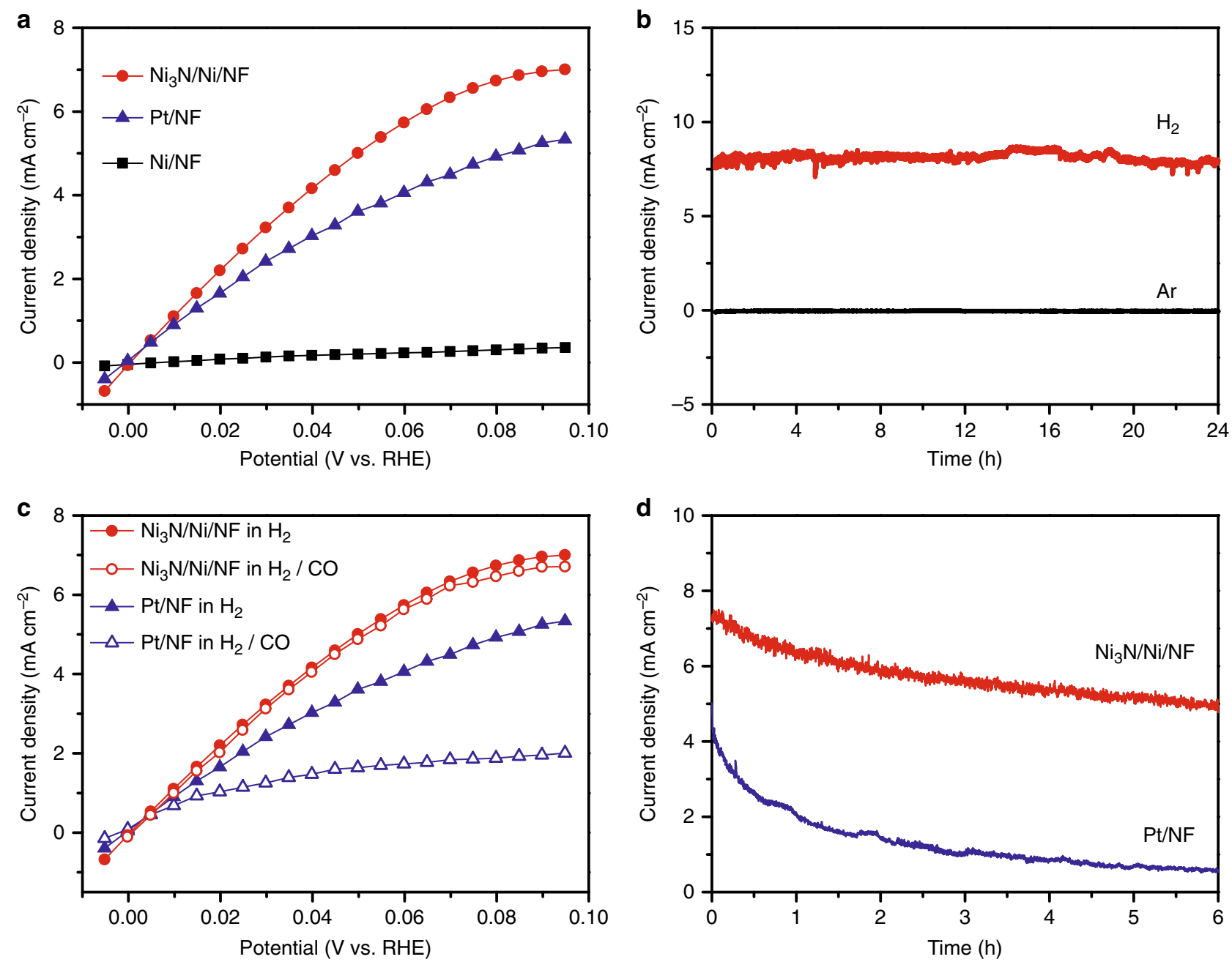

Fig. 4 The electrocatalytic performance for $\mathrm{HOR}$. a Steady-state polarization curves of $\mathrm{Ni}_{3} \mathrm{~N} / \mathrm{Ni} / \mathrm{NF}, \mathrm{Ni} / \mathrm{NF}$, and Pt/NF for $\mathrm{HOR}$ in $\mathrm{H}_{2}$-saturated $0.1 \mathrm{M} \mathrm{KOH}$. b Chronoamperometry curves of $\mathrm{Ni}_{3} \mathrm{~N} / \mathrm{Ni} / \mathrm{NF}$ in $\mathrm{H}_{2}$ - or Ar-saturated $0.1 \mathrm{M} \mathrm{KOH}$ measured at $0.09 \mathrm{~V}$ vs. RHE. c Comparison of the HOR polarization curves of $\mathrm{Ni}_{3} \mathrm{~N} / \mathrm{Ni} / \mathrm{NF}$ and $\mathrm{Pt} / \mathrm{NF}$ in $0.1 \mathrm{M} \mathrm{KOH}$ saturated with $\mathrm{H}_{2}$ or $\mathrm{H}_{2}$ with $2 \% \mathrm{CO}(\mathrm{v} / \mathrm{v})$. d Chronoamperometry curves of $\mathrm{Ni} 3 \mathrm{~N} / \mathrm{Ni} / \mathrm{NF}$ and Pt/NF in $0.1 \mathrm{M} \mathrm{KOH}$ saturated with $\mathrm{H}_{2}$ with $2 \% \mathrm{CO}(\mathrm{v} / \mathrm{v})$ measured at $0.09 \mathrm{~V}$ vs. RHE. All results were collected without iR compensation. The current densities were calculated on the basis of the geometric electrode areas

that collected in the absence of $\mathrm{H}_{2}$ (Fig. $4 \mathrm{~b}$ ). $\mathrm{Ni}_{3} \mathrm{~N} / \mathrm{Ni} / \mathrm{NF}$ maintained a stable anodic current density of $c a .8 \mathrm{~mA} \mathrm{~cm}^{-2}$ for $24 \mathrm{~h}$ when $\mathrm{H}_{2}$ was bubbled through the electrolyte, while negligible current density was obtained in Ar-saturated 0.1 M KOH. In sharp contrast, if $\mathrm{Ni} / \mathrm{NF}$ was utilized as the working electrode, no more than $0.5 \mathrm{~mA} \mathrm{~cm}^{-2}$ could be obtained in $\mathrm{H}_{2}$-saturated electrolyte (Supplementary Fig. 50).

In addition, the $\mathrm{HOR}$ performance of $\mathrm{Ni}_{3} \mathrm{~N} / \mathrm{Ni} / \mathrm{CF}$ and $\mathrm{Ni}_{3} \mathrm{~N} / \mathrm{NF}$ was also measured under the same condition as $\mathrm{Ni}_{3} \mathrm{~N} / \mathrm{Ni} / \mathrm{NF} . \mathrm{Ni}_{3} \mathrm{~N} /$ $\mathrm{Ni} / \mathrm{CF}$ exhibited appreciable anodic current for HOR, although its activity and stability were lower than those of $\mathrm{Ni}_{3} \mathrm{~N} / \mathrm{Ni} / \mathrm{NF}$, most likely due to the inferior porosity of carbon foam for $\mathrm{H}_{2}$ diffusion (Supplementary Figs. 51-52). On the other hand, $\mathrm{Ni}_{3} \mathrm{~N} / \mathrm{NF}$ only showed negligible anodic current for HOR, highlighting the advantages of utilizing rough and porous $\mathrm{Ni} / \mathrm{NF}$ as the $\mathrm{Ni}$ source for the preparation of $\mathrm{Ni}_{3} \mathrm{~N} / \mathrm{Ni} / \mathrm{NF}$ (Supplementary Fig. 53). Since the hydrogen $\left(\mathrm{H}^{*}\right)$ adsorption free energy $\left(\Delta \mathrm{G}_{\mathrm{H}^{*}}\right)$ is also regarded as a key descriptor in determining HOR activity $6,8,9,67$, the very small $\Delta \mathrm{G}_{\mathrm{H}^{*}}$ value $(0.01 \mathrm{eV})$ of $\mathrm{Ni}_{3} \mathrm{~N} / \mathrm{Ni} / \mathrm{NF}$ mentioned above also supports its excellent $\mathrm{HOR}$ performance (Fig. $3 \mathrm{~b}$ ). In addition, we further evaluated the adsorption energies of $\mathrm{H}_{2}$ on $\mathrm{Ni}_{3} \mathrm{~N} / \mathrm{Ni}$ interface, $\mathrm{Ni}_{3} \mathrm{~N}$, and $\mathrm{Ni}$ via DFT calculation (Supplementary Figs. $54-60$ ). $\mathrm{Ni}_{3} \mathrm{~N} / \mathrm{Ni}$ interface and $\mathrm{Ni}$ possess stronger $\mathrm{H}_{2}$ adsorption than $\mathrm{Ni}_{3} \mathrm{~N}$, indicating favored $\mathrm{H}_{2}$ adsorption on $\mathrm{Ni}_{3} \mathrm{~N} / \mathrm{Ni}$ and $\mathrm{Ni}$. Overall, given both its ideal $\Delta \mathrm{G}_{\mathrm{H}^{*}}$ value and strong $\mathrm{H}_{2}$ adsorption, $\mathrm{Ni}_{3} \mathrm{~N} / \mathrm{Ni}$ was DFT computationally predicted to be a great HOR electrocatalyst, in agreement with the aforementioned experimental results.

Since the current industrial production of $\mathrm{H}_{2}$ mainly relies on steam reforming from hydrocarbons, which may result in $\mathrm{CO}$ impurity in the final $\mathrm{H}_{2}$ gas. Therefore, high tolerance to $\mathrm{CO}$ impurity is a desirable property of electrocatalysts in hydrogen fuel cells. Unfortunately, CO poisoning is notoriously intolerable for Pt-based HOR electrocatalysts. Herein, we conducted $\mathrm{CO}$ tolerance tests in an extreme case wherein a $\mathrm{H}_{2}$ gas mixture with $2 \% \mathrm{CO}(\mathrm{v} / \mathrm{v})$ was utilized. As shown in Fig. $4 \mathrm{c}$, the HOR activity of $\mathrm{Pt} / \mathrm{NF}$ indeed was strongly suppressed by the presence of $\mathrm{CO}$, as its steady-state HOR polarization curves decreased substantially in the $\mathrm{H}_{2} / \mathrm{CO}$ mixture relative to that in pure $\mathrm{H}_{2}$. For instance, at $0.09 \mathrm{~V}$ vs. RHE, the maximum current density of Pt/ $\mathrm{NF}$ decreased by $\sim 63 \%$ from 5.25 to $1.95 \mathrm{~mA} \mathrm{~cm}^{-2}$. On the other hand, $\mathrm{Ni}_{3} \mathrm{~N} / \mathrm{Ni} / \mathrm{NF}$ demonstrated a much better resistance towards $\mathrm{CO}$ poisoning, showing a much less decrease of its HOR polarization in the presence of CO. In fact, the maximum current density achieved at $0.09 \mathrm{~V}$ vs. RHE was only decreased by $3.5 \%$ on $\mathrm{Ni}_{3} \mathrm{~N} / \mathrm{Ni} / \mathrm{NF}$, from 6.95 to $6.71 \mathrm{~mA} \mathrm{~cm}^{-2}$. Next, chronoamperometry at $0.09 \mathrm{~V}$ vs. RHE was also conducted to 
further evaluate their $\mathrm{CO}$ tolerance. As shown in Fig. 4d, a rapid current decrease was observed for $\mathrm{Pt} / \mathrm{NF}$ in $\mathrm{H}_{2} / \mathrm{CO}$-saturated 0.1 $\mathrm{M} \mathrm{KOH}$, resulting in a merely $0.57 \mathrm{~mA} \mathrm{~cm}^{-2}$ after $6 \mathrm{~h}$ electrolysis. In contrast, $\mathrm{Ni}_{3} \mathrm{~N} / \mathrm{Ni} / \mathrm{NF}$ was able to retain above $5 \mathrm{~mA} \mathrm{~cm}-2$ under the same conditions. These results unambiguously proved that our $\mathrm{Ni}_{3} \mathrm{~N} / \mathrm{Ni} / \mathrm{NF}$ showed exceptional CO tolerance for HOR, even though our testing conditions utilized a CO percentage at least two orders higher than those typically reported ${ }^{68}$.

\section{Discussion}

In summary, we have demonstrated that interfacing $\mathrm{Ni}_{3} \mathrm{~N}$ and $\mathrm{Ni}$ on metallic nickel foam is an effective approach to producing highly active and robust electrocatalysts for both $\mathrm{H}_{2}$ evolution and oxidation reactions in aqueous media. The resultant $\mathrm{Ni}_{3} \mathrm{~N} /$ $\mathrm{Ni} / \mathrm{NF}$ catalyzes HER/HOR starting at zero overpotential, robust long-term durability, and great tolerance to $\mathrm{CO}$ poisoning. The superior electrocatalytic performance makes $\mathrm{Ni}_{3} \mathrm{~N} / \mathrm{Ni} / \mathrm{NF}$ the most active catalyst among most of the reported inexpensive electrocatalysts and it can even rival the activities of the state-ofthe-art $\mathrm{Pt} / \mathrm{C}$ catalysts loaded on NF under similar experimental conditions. A suite of physical characterizations, electrochemical experiments, together with theoretical computations, were conducted to gain the insights into the exceptional HER/HOR activities of $\mathrm{Ni}_{3} \mathrm{~N} / \mathrm{Ni} / \mathrm{NF}$, which can be summarized in the following aspects.

The unique electronic and geometrical structures of the interfacial sites on $\mathrm{Ni}_{3} \mathrm{~N} / \mathrm{Ni}$ provide great accommodation for hydrogen adsorption. As estimated from DFT calculations, the free energy change of hydrogen adsorption at the interfacial sites of $\mathrm{Ni}_{3} \mathrm{~N} / \mathrm{Ni} / \mathrm{NF}$ is very close to zero, which is beneficial to hydrogen electrochemistry ${ }^{66}$. Although fully considering the solvent environment and taking into account of water adsorption when calculating the hydrogen adsorption are challenging and beyond the scope of this work, our ongoing work aims to compute the apparent hydrogen adsorption energy, which has been recently proposed as a $\mathrm{pH}$-dependent descriptor for HER and HOR activities ${ }^{69}$.

Due to the lack of free protons in neutral and alkaline electrolytes, water adsorption, and dissociation have been proposed to be critical for HER at high $\mathrm{pH}$. Our computational results suggest that the interface between $\mathrm{Ni}_{3} \mathrm{~N}$ and $\mathrm{Ni}$ significantly promotes the initial water adsorption and reduces the energy barrier for the subsequent water dissociation compared to the situations on pure $\mathrm{Ni}$ or $\mathrm{Ni}_{3} \mathrm{~N}$. The $\mathrm{Ni}_{3} \mathrm{~N} / \mathrm{Ni}$ interface may also lower the energy barrier for the reorganization of the interfacial water network and enable efficient proton/hydroxide transfer through the double layer, thereby promoting the HER/HOR kinetics $^{72}$. Another possible factor that cannot be completely excluded is the potential formation of nickel oxides/hydroxides on the surface of $\mathrm{Ni}_{3} \mathrm{Ni} / \mathrm{Ni} / \mathrm{NF}$ during HER/HOR testing. Despite the debate over the promotional effect of interface oxophilicity $6,25,65-67,70,71$, Markovic et al. proposed that regulating metal/ metal (oxy)hydroxide interface can promote water dissociation for HER and optimize the balance between the active sites for $\mathrm{H}_{2}$ adsorption/dissociation and the sites for hydroxyl adsorption, in order to enhance the alkaline $\mathrm{HOR}^{30-33}$. Analogous enhancement due to surface nickel oxides/hydroxides may also exist, however it should not be attributed as the primary factor, because the control sample $\mathrm{Ni} / \mathrm{NF}$, which should have similar tendency to form surface nickel oxides/hydroxide species, does not exhibit appreciable HER or HOR performance.

The intimate contact between the $\mathrm{Ni}_{3} \mathrm{~N} / \mathrm{Ni}$ nanoparticles and the nickel foam substrate as well as the intrinsically metallic properties of both $\mathrm{Ni}_{3} \mathrm{~N}$ and $\mathrm{Ni}$ enable fast electron transfer between the active sites and the current collector. The hierarchical topology and highly porous morphology of $\mathrm{Ni}_{3} \mathrm{~N} / \mathrm{Ni} / \mathrm{NF}$ not only maximize the accessibility of active sites but also facilitate mass transport, which are all beneficial to electrocatalytic $\mathrm{H}_{2}$ evolution and oxidation reactions.

\section{Methods}

Syntheses of $\mathbf{N i} / \mathbf{N F}$ and $\mathbf{N i}_{3} \mathbf{N} / \mathbf{N i} / \mathbf{N F}$. The $\mathrm{Ni}_{3} \mathrm{~N} / \mathrm{Ni} / \mathrm{NF}$ electrodes were prepared by cathodic electrodeposition of Ni particles on nickel foams followed by thermal nitridation. The electrodeposition was carried out with a two-electrode configuration in a cell containing $\mathrm{NH}_{4} \mathrm{Cl}(2.0 \mathrm{M})$ and $\mathrm{NiCl}_{2}(0.1 \mathrm{M})$ at room temperature. A piece of clean nickel foam $(0.5 \mathrm{~cm} \times 0.5 \mathrm{~cm})$ and a carbon rod were used as the working and counter electrodes, respectively. The electrodeposition was performed at a constant current density of $-1.0 \mathrm{~A} \mathrm{~cm}^{-2}$ for $500 \mathrm{~s}$ under $\mathrm{N}_{2}$ protection without stirring to obtain Ni/NF. Then the resultant Ni/NF was placed in the center of a quartz tube purged with $\mathrm{NH}_{3}$ flow. It was heated to the desired temperature at a ramping rate of $10^{\circ} \mathrm{C} \mathrm{min}^{-1}$ and maintained at the same temperature for a given duration. Finally, the furnace was naturally cooled down to room temperature, leading to $\mathrm{Ni}_{3} \mathrm{~N} / \mathrm{Ni} / \mathrm{NF}$. The $\mathrm{NH}_{3}$ flow was kept throughout the whole process. Two control samples of $\mathrm{Ni}_{3} \mathrm{~N} / \mathrm{Ni} / \mathrm{CF}$ and $\mathrm{Ni}_{3} \mathrm{~N} / \mathrm{NF}$ were also synthesized under same conditions for comparison (see Supplementary Information).

Electrocatalytic measurements. The linear sweep voltammetry (LSV), cyclic voltammetry (CV), chronopotentiometry (CP), and chronoamperometry (CA) experiments were conducted using a Gamry Interface 1000 electrochemical workstation with a three-electrode configuration. The monolithic $\mathrm{Ni}_{3} \mathrm{~N} / \mathrm{Ni} / \mathrm{NF}$ was directly used as the working electrode. A calibrated $\mathrm{Ag} / \mathrm{AgCl}$ (saturated $\mathrm{KCl}$ ) with salt bridge kit and a carbon rod were used as the reference and counter electrode, respectively. The electrolyte for HER was $1.0 \mathrm{M}$ potassium phosphate buffer (KPi, $\mathrm{pH} 7.17$ ), or $1.0 \mathrm{M} \mathrm{KOH}$ ( $\mathrm{pH} 13.80)$. The electrolyte for HOR was $0.1 \mathrm{M} \mathrm{KOH} \mathrm{(pH}$ 12.80). All electrolytes were bubbled with $\mathrm{H}_{2}$ throughout the whole electrochemical experiments. All potentials are reported versus reversible hydrogen electrode (RHE) according to the following equation:

$$
E(\text { vs. RHE })=E(\text { vs. Ag } / \mathrm{AgCl})+0.197+0.059 \times \mathrm{pH}
$$

$\mathrm{Hg} / \mathrm{HgO}$ (1.0 M KOH, CH Instruments) and $\mathrm{Hg} / \mathrm{Hg}_{2} \mathrm{SO}_{4}$ (saturated $\mathrm{K}_{2} \mathrm{SO}_{4}, \mathrm{CH}$ Instruments) reference electrodes were also used to verify the electrocatalytic performances which were consistent with the results referenced to $\mathrm{Ag} / \mathrm{AgCl}$ (saturated $\mathrm{KCl}$ ) electrodes. The LSV and CV curves were collected at $5 \mathrm{mV} \mathrm{s}^{-1}$. Unless stated otherwise, all LSV polarization curves for HER were iR-corrected and obtained by scanning from negative to positive potential. The correction was made according to the following equation:

$$
E_{\text {corrected }}=E_{\text {measured }}-i R_{\mathrm{s}}
$$

where $E_{\text {corrected }}$ is the $i R$-corrected potential, $E_{\text {measured }}$ and $i$ are experimentally measured potential and current, respectively, and $R_{\mathrm{s}}$ is the equivalent series resistance measured via electrochemical impedance spectroscopy in the frequency range of $10^{6}-0.1 \mathrm{~Hz}$ with an amplitude of $10 \mathrm{mV}$

For HOR tests, the steady-state measurements were conducted to obtain the polarization curves instead of LSV or CV methods to minimize the capacitive current background. The multi-step CA was conducted at a potential window from -0.05 to $0.1 \mathrm{~V}$ vs. RHE with a $5 \mathrm{mV}$ interval for every $60 \mathrm{~s}$. The stable anodic current recorded at $60 \mathrm{~s}$ under each potential was used to plot the steady-state polarization curves for HOR. For comparison, the polarization curves towards HOR were also collected in $0.1 \mathrm{M} \mathrm{KOH}$ bubbled with high-purity $\mathrm{H}_{2}$ or $\mathrm{H}_{2}$ containing $2 \% \mathrm{CO}(\mathrm{v} / \mathrm{v})$. The catalytic stability for HER/HOR was evaluated by either CP or CA measurement without iR correction. Besides $\mathrm{Ni}_{3} \mathrm{~N} / \mathrm{Ni} / \mathrm{NF}$, the electrodeposited $\mathrm{Ni} / \mathrm{NF}, \mathrm{Ni}_{3} \mathrm{~N} / \mathrm{Ni} / \mathrm{CF}, \mathrm{Ni}_{3} \mathrm{~N} / \mathrm{NF}$ and commercial $\mathrm{Pt} / \mathrm{C}$ catalysts loaded on nickel foams with optimized loading were also used as working electrodes for both HER and HOR. For HER, the optimal loading of Pt/C powder on nickel foam (Pt/NF) was $2.5 \mathrm{mg} \mathrm{cm}^{-2}$ in $1.0 \mathrm{M} \mathrm{KPi}$ and $1.0 \mathrm{M} \mathrm{KOH}$. For HOR in $0.1 \mathrm{M} \mathrm{KOH}$, the optimal loading of $\mathrm{Pt} / \mathrm{C}$ on nickel foam $(\mathrm{Pt} / \mathrm{NF})$ was $1.5 \mathrm{mg} \mathrm{cm}$ -2 . The current densities in this work were calculated on the basis of the geometric areas, BET surface areas, or electrochemically active surface areas (ECSAs) of electrodes.

The exchange current $\left(i_{0}\right)$ can be obtained by fitting kinetic current $\left(i_{\mathrm{k}}\right)$ versus the overpotential $(\eta)$ using the Butler-Volmer Eq. (3),

$$
i_{\mathrm{k}}=i_{0}\left(e^{\frac{\alpha F}{R T} \eta}-e^{\frac{(\alpha-1) F}{R T} \eta}\right)
$$

where $\alpha$ is the charge transfer coefficient, $\eta$ is the overpotential, $R$ is the ideal gas constant $\left(8.314 \mathrm{~J} \mathrm{~mol}^{-1} \mathrm{~K}^{-1}\right), T$ is the experimental temperature $(298 \mathrm{~K})$, and $F$ is the Faradaic constant $\left(96,485 \mathrm{C} \mathrm{mol}^{-1}\right)$.

In a small potential window of the micro-polarization region near the equilibrium potential $\left( \pm 20 \mathrm{mV}\right.$ vs. RHE), $i_{\mathrm{k}}$ approximately equals to the measured current $(i)$. In this case, the Butler-Volmer equation can be expanded by Taylor's 
formula and simplified as Eq. (4),

$$
i=i_{0} \frac{\eta F}{R T}
$$

Therefore, $i_{0}$ can be obtained from the slope of the linear fitting in the micropolarization region ${ }^{5,25,72}$. The exchange current density $\left(j_{0}\right)$ was calculated by dividing $i_{0}$ by the geometric electrode area.

Theoretical computation. The DFT calculations were performed with Vienna Ab initio Simulation Package (VASP) version 5.4 ${ }^{73-76}$. The projector augmented-wave (PAW) potentials ${ }^{77}$ were used, with $1 \mathrm{~s}$ of $\mathrm{H}, 2 \mathrm{~s} 2 \mathrm{p}$ of $\mathrm{N}$ and $\mathrm{O}$, and $3 \mathrm{~d} 4 \mathrm{~s}$ of $\mathrm{Ni}$ treated as valence electrons. The generalized gradient approximation (GGA) of Perdew, Burke, and Ernzerhof (PBE) ${ }^{78}$ was employed. A cutoff energy of $450 \mathrm{eV}$ was used for the plane-wave basis set. The Brillouin zone was sampled by Monkhorst-Pack k-point mesh, with reciprocal lattice spacing $\leq 0.04 \AA^{-1}$. These settings converge the total energy to $\leq 1 \mathrm{meV} /$ atom with respect to higher kinetic energy cutoff or denser k-point mesh. The convergence criterion for structural optimization was set to $0.025 \mathrm{eV} / \AA$ for each atom.

The optimized bulk face centered cubic Ni structure has a lattice constant of $3.515 \AA$ (experimental lattice constant is equal to $3.523 \AA^{79}$. The lattice constants for optimized bulk hexagonal $\mathrm{Ni}_{3} \mathrm{~N}$ are $a=4.612 \AA, c=4.302 \AA$ (experimental values: $a=4.622 \AA$ and $c=4.306 \AA^{79}$ ). Predicted lattice constants for both materials deviate $<0.3 \%$ from their corresponding experimental values. The optimized bulk structures were used to construct surface slab models. A $(4 \times 4) \mathrm{Ni}$ (111) slab model of five layers was used for pure $\mathrm{Ni}$, with the bottom two layers of $\mathrm{Ni}$ atoms fixed to mimic bulk structure. For $\mathrm{Ni}_{3} \mathrm{~N}$, a N-terminated $(2 \times 2) \mathrm{Ni}_{3} \mathrm{~N}$ (001) surface slab of 10 layers was built, with the bottom four layers fixed. For the hybrid model, a four-layer $(6 \times 3) \mathrm{Ni}(111)$ slab was constructed, with the bottom two layers fixed and an $\mathrm{Ni}_{3} \mathrm{~N}$ nanowire placed on top. The nanowire consists of four layers of $\mathrm{Ni}_{3} \mathrm{~N}$ (001), with $\mathrm{N}$ termination interacting with $\mathrm{Ni}$ (111) surface to make an effective interface. While both $\mathrm{Ni}$ layers in $\mathrm{Ni}(111)$ and $\mathrm{Ni}_{3} \mathrm{~N}(001)$ form hexagonal array, the nearest $\mathrm{Ni}-\mathrm{Ni}$ distance in $\mathrm{Ni}_{3} \mathrm{~N}(001)$ planes is $\sim 8 \%$ longer than its counterpart in $\mathrm{Ni}(111)$. Therefore, the $\mathrm{Ni}_{3} \mathrm{~N}$ nanowire in the hybrid model experiences compressive strain from $\mathrm{Ni}$ substrate. The two sides of the nanowire correspond to N-terminated (110) surface of $\mathrm{Ni}_{3} \mathrm{~N}$.

The adsorption energy of hydrogen was defined as $E_{\text {slab-H }}-\left(E_{\text {slab }}+\frac{1}{2} E_{\mathrm{H}_{2}}\right)$. Zero-point energy and entropic corrections were included for calculating the Gibbs free energy correlations (see Supplementary Information for more details). The reaction pathway was simulated by the climbing image nudged elastic band (CI-NEB) 80 and the dimer ${ }^{81}$ method.

\section{Data availability}

The data that support the findings of this study are available from the corresponding authors on reasonable request.

Received: 19 April 2018 Accepted: 28 August 2018

Published online: 31 October 2018

\section{References}

1. Turner, J. A. Sustainable hydrogen production. Science 305, 972-974 (2004).

2. Stamenkovic, V. R., Strmcnik, D., Lopes, P. P. \& Markovic, N. M. Energy and fuels from electrochemical interfaces. Nat. Mater. 16, 57-69 (2017).

3. Seh, Z. W. et al. Combining theory and experiment in electrocatalysis: Insights into materials design. Science 355, eaad4998 (2017).

4. Debe, M. K. Electrocatalyst approaches and challenges for automotive fuel cells. Nature 486, 43-51 (2012)

5. Cong, Y., Yi, B. \& Song, Y. Hydrogen oxidation reaction in alkaline media: From mechanism to recent electrocatalysts. Nano Energy 44, 288-303 (2018).

6. Sheng, W. et al. Correlating hydrogen oxidation and evolution activity on platinum at different $\mathrm{pH}$ with measured hydrogen binding energy. Nat Commun. 6, 5848 (2015).

7. Setzler, B. P., Zhuang, Z., Wittkopf, J. A. \& Yan, Y. Activity targets for nanostructured platinum-group-metal-free catalysts in hydroxide exchange membrane fuel cells. Nat. Nanotech. 11, 1020-1025 (2016).

8. Zhuang, Z. et al. Nickel supported on nitrogen-doped carbon nanotubes as hydrogen oxidation reaction catalyst in alkaline electrolyte. Nat. Commun. 7, 10141 (2016).

9. Sheng, W. et al. Non-precious metal electrocatalysts with high activity for hydrogen oxidation reaction in alkaline electrolytes. Energy Environ. Sci. 7, 1719-1724 (2014).

10. Varcoe, J. R. et al. Anion-exchange membranes in electrochemical energy systems. Energy Environ. Sci. 7, 3135-3191 (2014).

11. Gottesfeld, S. et al. Anion exchange membrane fuel cells: current status and remaining challenges. J. Power Sources 375, 170-184 (2018).
12. Serov, A., Zenyuk, I. V., Arges, C. G. \& Chatenet, M. Hot topics in alkaline exchange membrane fuel cells. J. Power Sources 375, 149-157 (2018).

13. Urban, J. J. Emerging scientific and engineering opportunities within the water-energy nexus. Joule 1, 665-688 (2017).

14. McCrory, C. C. L. et al. Benchmarking hydrogen evolving reaction and oxygen evolving reaction electrocatalysts for solar water splitting devices. J. Am. Chem. Soc. 137, 4347-4357 (2015).

15. Zhang, J. et al. Efficient hydrogen production on $\mathrm{MoNi}_{4}$ electrocatalysts with fast water dissociation kinetics. Nat. Commun. 8, 15437 (2017).

16. $\mathrm{Li}, \mathrm{W}$. et al. Hydrothermal synthesis of monolithic $\mathrm{Co}_{3} \mathrm{Se}_{4}$ nanowire electrodes for oxygen evolution and overall water splitting with high efficiency and extraordinary catalytic stability. Adv. Energy Mater. 7, 1602579 (2017).

17. Kibsgaard, J., Chen, Z., Reinecke, B. N. \& Jaramillo, T. F. Engineering the surface structure of $\mathrm{MoS}_{2}$ to preferentially expose active edge sites for electrocatalysis. Nat. Mater. 11, 963-969 (2012).

18. $\mathrm{Li}, \mathrm{W}$. et al. Electrolyzer design for flexible decoupled water splitting and organic upgrading with electron reservoirs. Chem 4, 637-649 (2018).

19. Song, F., Li, W., Han, G. \& Sun, Y. Electropolymerization of aniline on nickelbased electrocatalysts substantially enhances their performance for hydrogen evolution. ACS Appl. Energy Mater. 1, 3-8 (2018).

20. Gao, L. et al. A nickel nanocatalyst within a h-BN shell for enhanced hydrogen oxidation reactions. Chem. Sci. 8, 5728-5734 (2017).

21. $\mathrm{Hu}, \mathrm{Q}$. et al. Alkaline polymer electrolyte fuel cell with Ni-based anode and Co-based cathode. Int. J. Hydrogen Energy 38, 16264-16268 (2013).

22. Lu, S., Pan, J., Huang, A., Zhuang, L. \& Lu, J. Alkaline polymer electrolyte fuel cells completely free from noble metal catalysts. Proc. Natl Acad. Sci. USA 105, 20611-20614 (2008)

23. Kabir, S. et al. Platinum group metal-free NiMo hydrogen oxidation catalysts: high performance and durability in alkaline exchange membrane fuel cells. $J$. Mater. Chem. A 5, 24433-24443 (2017).

24. Sheng, W., Myint, M., Chen, J. G. \& Yan, Y. Correlating the hydrogen evolution reaction activity in alkaline electrolytes with the hydrogen binding energy on monometallic surfaces. Energy Environ. Sci. 6, 1509-1512 (2013).

25. Lu, S. \& Zhuang, Z. Investigating the influences of the adsorbed species on catalytic activity for hydrogen oxidation reaction in alkaline electrolyte. J. Am. Chem. Soc. 139, 5156-5163 (2017).

26. Laursen, A. B. et al. Electrochemical hydrogen evolution: Sabatier's principle and the Volcano plot. J. Chem. Educ. 89, 1595-1599 (2012).

27. Nørskov, J. K. et al. Trends in the exchange current for hydrogen evolution. J. Electrochem. Soc. 152, J23-J26 (2005).

28. Staszak-Jirkovský, J. et al. Design of active and stable Co-Mo-S $\mathrm{S}_{\mathrm{x}}$ chalcogels as $\mathrm{pH}$-universal catalysts for the hydrogen evolution reaction. Nat. Mater. 15, 197-203 (2016).

29. Mahmood, J. et al. An efficient and $\mathrm{pH}$-universal ruthenium-based catalyst for the hydrogen evolution reaction. Nat. Nanotech. 12, 441-446 (2017).

30. Subbaraman, R. et al. Enhancing hydrogen evolution activity in water splitting by tailoring $\mathrm{Li}^{+}-\mathrm{Ni}(\mathrm{OH})_{2}$-Pt Interfaces. Science 334, 1256-1260 (2011).

31. Danilovic, N. et al. Enhancing the alkaline hydrogen evolution reaction activity through the bifunctionality of $\mathrm{Ni}(\mathrm{OH})_{2} /$ metal catalysts. Angew. Chem. Int. Ed. 51, 12495-12498 (2012).

32. Subbaraman, R. et al. Trends in activity for the water electrolyser reactions on 3d M (Ni,Co,Fe,Mn) hydr(oxy)oxide catalysts. Nat. Mater. 11, 550-557 (2012)

33. Strmcnik, D. et al. Improving the hydrogen oxidation reaction rate by promotion of hydroxyl adsorption. Nat. Chem. 5, 300-306 (2013).

34. Zeng, Z., Chang, K.-C., Kubal, J., Markovic, N. M. \& Greeley, J. Stabilization of ultrathin (hydroxy)oxide films on transition metal substrates for electrochemical energy conversion. Nat. Energy 2, 17070 (2017).

35. Ledendecker, M., Schlott, H., Antonietti, M., Meyer, B. \& Shalom, M. Experimental and theoretical assessment of Ni-based binary compounds for the hydrogen evolution reaction. Adv. Energy Mater. 7, 1601735 (2017).

36. Li, W. et al. Self-supported Co-Ni-P ternary nanowire electrodes for highly efficient and stable electrocatalytic hydrogen evolution in acidic solution. Catal. Today 287, 122-129 (2017).

37. Gage, S. H., Trewyn, B. G., Ciobanu, C. V., Pylypenko, S. \& Richards, R. M. Synthetic advancements and catalytic applications of nickel nitride. Catal. Sci. Technol. 6, 4059-4076 (2016).

38. Jia, Y. et al. Synthesis of $\mathrm{Ni}_{3} \mathrm{~N} / \mathrm{SiO}_{2}$ nanocomposites and investigation of their intrinsic static and dynamic magnetic properties. RSC Adv. 5, 14061-14064 (2015)

39. $\mathrm{Xu}, \mathrm{K}$. et al. Metallic nickel nitride nanosheets realizing enhanced electrochemical water oxidation. J. Am. Chem. Soc. 137, 4119-4125 (2015).

40. Balogun, M.-S. et al. Three-dimensional nickel nitride $\left(\mathrm{Ni}_{3} \mathrm{~N}\right)$ nanosheets: free standing and flexible electrodes for lithium ion batteries and supercapacitors. J. Mater. Chem. A 4, 9844-9849 (2016).

41. Liu, T. et al. Design and synthesis of integrally structured $\mathrm{Ni}_{3} \mathrm{~N}$ nanosheets/ carbon microfibers $/ \mathrm{Ni}_{3} \mathrm{~N}$ nanosheets for efficient full water splitting catalysis. J. Mater. Chem. A 5, 9377-9390 (2017). 
42. Gao, D. et al. Metallic $\mathrm{Ni}_{3} \mathrm{~N}$ nanosheets with exposed active surface sites for efficient hydrogen evolution. J. Mater. Chem. A 4, 17363-17369 (2016).

43. Park, S. H. et al. Nickel-nitride-coated nickel foam as a counter electrode for dye-sensitized solar cells. Surf. Coat. Technol. 259, 560-569 (2014).

44. Wang, Y., Fu, Z.-W., Yue, X.-L. \& Qin, Q.-Z. Electrochemical reactivity mechanism of $\mathrm{Ni}_{3} \mathrm{~N}$ with lithium. J. Electrochem. Soc. 151, E162-E167 (2004).

45. Cao, B., Veith, G. M., Neuefeind, J. C., Adzic, R. R. \& Khalifah, P. G. Mixed close-packed cobalt molybdenum nitrides as non-noble metal electrocatalysts for the hydrogen evolution reaction. J. Am. Chem. Soc. 135, 19186-19192 (2013).

46. Wu, A. et al. Integrating the active OER and HER components as the heterostructures for the efficient overall water splitting. Nano Energy 44, 353-363 (2018).

47. You, B. et al. Universal surface engineering of transition metals for superior electrocatalytic hydrogen evolution in neutral water. J. Am. Chem. Soc. 139, 12283-12290 (2017).

48. Sun, S., Li, H. \& Xu, Z. J. Impact of surface area in evaluation of catalyst activity. Joule 2, 1024-1027 (2018).

49. Yoon, Y., Yan, B. \& Surendranath, Y. Suppressing ion transfer enables versatile measurements of electrochemical surface area for intrinsic activity comparisons. J. Am. Chem. Soc. 140, 2397-2400 (2018).

50. Vrubel, H. \& Hu, X. L. Molybdenum boride and carbide catalyze hydrogen evolution in both acidic and basic solutions. Angew. Chem. Int. Ed. 51, 12703-12706 (2012).

51. Bockris, J. O'M. \& Potter, E. C. The mechanism of the cathodic hydrogen evolution reaction. J. Electrochem. Soc. 99, 169-186 (1952).

52. Conway, B. E. \& Bai, L. J. Determination of adsorption of OPD H species in the cathodic hydrogen evolution reaction at $\mathrm{Pt}$ in relation to electrocatalysis. J. Electroanal. Chem. 198, 149-175 (1986).

53. Conway, B. E., Bai, L. J. \& Sattar, M. A. Role of the transfer coefficient in electrocatalysis: applications to the $\mathrm{H}_{2}$ and $\mathrm{O}_{2}$ evolution reactions and the characterization of participating adsorbed intermediates. Int. J. Hydrogen Energy 12, 607-621 (1987).

54. Popczun., E. J. et al. Nanostructured nickel phosphide as an electrocatalyst for the hydrogen evolution reaction. J. Am. Chem. Soc. 135, 9267-9270 (2013).

55. Hansen, M. H., Stern, L. A., Feng, L. G., Rossmeisl, J. \& Hu, X. L. Widely available active sites on $\mathrm{Ni}_{2} \mathrm{P}$ for electrochemical hydrogen evolution-insights from first principles calculations. Phys. Chem. Chem. Phys. 17, 10823-10829 (2015).

56. Kibsgaard, J. \& Jaramillo, T. F. Molybdenum phosphosulfide: an active, acidstable, earth-abundant catalyst for the hydrogen evolution reaction. Angew. Chem. Int. Ed. 53, 14433-14437 (2014).

57. Yu, F. et al. High-performance bifunctional porous non-noble metal phosphide catalyst for overall water splitting. Nat. Commun. 9, 2551 (2018).

58. Shinagawa, T., Garcia-Esparza, A. T. \& Takanabe, K. Insight on Tafel slopes from a microkinetic analysis of aqueous electrocatalysis for energy conversion. Sci. Rep. 5, 13801 (2015)

59. Zheng, J., Yan, Y. S. \& Xu, B. J. Correcting the hydrogen diffusion limitation in rotating disk electrode measurements of hydrogen evolution reaction kinetics. J. Electrochem. Soc. 162, F1470-F1481 (2015).

60. Cabán-Acevedo, M. et al. Efficient hydrogen evolution catalysis using ternary pyrite-type cobalt phosphosulphide. Nat. Mater. 14, 1245-1251 (2015).

61. Cheng, N. et al. Platinum single-atom and cluster catalysis of the hydrogen evolution reaction. Nat. Commun. 7, 13638 (2016).

62. Chen, J. G. Carbide and nitride overlayers on early transition metal surfaces: preparation, characterization, and reactivities. Chem. Rev. 96, 1477-1498 (1996).

63. Gao, M., Chen, L., Zhang, Z., Sun, X. \& Zhang, S. Interface engineering of the $\mathrm{Ni}(\mathrm{OH})_{2}-\mathrm{Ni}_{3} \mathrm{~N}$ nanoarray heterostructure for the alkaline hydrogen evolution reaction. J. Mater. Chem. A 6, 833-836 (2018).

64. Wang, Y., Chen, L., Yu, X., Wang, Y. \& Zheng, G. Superb alkaline hydrogen evolution and simultaneous electricity generation by Pt-decorated $\mathrm{Ni}_{3} \mathrm{~N}$ nanosheets. Adv. Energy Mater. 7, 1601390 (2017).

65. Koper, M. T. M. Hydrogen electrocatalysis: a basic solution. Nat. Chem. 5, 255-256 (2013).

66. Durst, J. et al. New insights into the electrochemical hydrogen oxidation and evolution reaction mechanism. Energy Environ. Sci. 7, 2255-2260 (2014).

67. Zheng, J., Sheng, W., Zhuang, Z., Xu, B. \& Yan, Y. Universal dependence of hydrogen oxidation and evolution reaction activity of platinum-group metals on $\mathrm{pH}$ and hydrogen binding energy. Sci. Adv. 2, e1501602 (2016).

68. Camara, G. A., Ticianelli, E. A., Mukerjee, S., Lee, S. J. \& McBreen, J. The CO poisoning mechanism of the hydrogen oxidation reaction in proton exchange membrane fuel cells. J. Electrochem. Soc. 149, A748-A753 (2002).

69. Zheng, J., Nash, J., Xu, B. \& Yan, Y. Perspective-towards establishing apparent hydrogen binding energy as the descriptor for hydrogen oxidation/evolution reactions. J. Electrochem. Soc. 165, H27-H29 (2018).

70. Ledezma-Yanez, I. et al. Interfacial water reorganization as a pH-dependent descriptor of the hydrogen evolution rate on platinum electrodes. Nat. Energy 2, 17031 (2017).
71. Wang, Y. et al. Pt-Ru catalyzed hydrogen oxidation in alkaline media: oxophilic effect or electronic effect? Energy Environ. Sci. 8, 177-181 (2015).

72. Lu, S. \& Zhuang, Z. Electrocatalysts for hydrogen oxidation and evolution reactions. Sci. China Mater. 59, 217-238 (2016).

73. Kresse, G. \& Hafner, J. Ab initio molecular dynamics for liquid metals. Phys Rev. B 47, 558-561 (1993).

74. Kresse, G. \& Hafner, J. Ab initio molecular-dynamics simulation of the liquidmetal-amorphous-semiconductor transition in germanium. Phys. Rev. B 49, 14251-14269 (1994).

75. Kresse, G. \& Furthmüller, J. Efficient iterative schemes for ab initio totalenergy calculations using a plane-wave basis set. Phys. Rev. B 54, 11169-11186 (1996).

76. Kresse, G. \& Furthmüller, J. Efficiency of ab-initio total energy calculations for metals and semiconductors using a plane-wave basis set. Comp. Mater. Sci. 6 15-50 (1996).

77. Blöchl, P. E. Projector augmented-wave method. Phys. Rev. B 50, 17953-17979 (1994).

78. Perdew, J. P., Burke, K. \& Ernzerhof, M. Generalized gradient approximation made simple. Phys. Rev. Lett. 77, 3865-3868 (1996).

79. Leineweber, A., Jacobs, H. \& Hull, S. Ordering of nitrogen in nickel nitride $\mathrm{Ni}_{3} \mathrm{~N}$ determined by neutron diffraction. Inorg. Chem. 40, 5818-5822 (2001).

80. Henkelman, G., Uberuaga, B. P. \& Jónsson, H. A climbing image nudged elastic band method for finding saddle points and minimum energy paths. J. Chem. Phys. 113, 9901-9904 (2000).

81. Henkelman, G. \& Jónsson, H. A dimer method for finding saddle points on high dimensional potential surfaces using only first derivatives. J. Chem. Phys. 111, 7010-7022 (1999).

\section{Acknowledgements}

This work was supported by the UTAG program of USTAR, State of Utah. Y.S. acknowledges the financial support of Herman Frasch Foundation (820-HF17), National Science Foundation (CHE-1653978), and the University of Cincinnati. We acknowledge the Microscopy Core Facility at USU. P.L. gratefully acknowledges the American Chemical Society Petroleum Research Fund for support of this research. The computational research was supported in part through computational resources provided by the Information Technology department at Purdue, West Lafayette, Indiana.

\section{Author contributions}

Y.S. designed and supervised the project, directed the research, analyzed and interpreted the data, and wrote the manuscript. F.S. and W.L. designed the methodology and conducted the experiments, synthesized samples, analyzed and interpreted the data, and wrote the manuscript. F.S. and W.L. contributed equally to this work. G.H. contributed to SEM and elemental mapping measurements. P.L. and J.Q. contributed to DFT computations. All of the authors discussed the results and reviewed the manuscript.

\section{Additional information}

Supplementary Information accompanies this paper at https://doi.org/10.1038/s41467018-06728-7.

Competing interests: The authors declare no competing interests.

Reprints and permission information is available online at http://npg.nature.com/ reprintsandpermissions/

Publisher's note: Springer Nature remains neutral with regard to jurisdictional claims in published maps and institutional affiliations.

Open Access This article is licensed under a Creative Commons Attribution 4.0 International License, which permits use, sharing, adaptation, distribution and reproduction in any medium or format, as long as you give appropriate credit to the original author(s) and the source, provide a link to the Creative Commons license, and indicate if changes were made. The images or other third party material in this article are included in the article's Creative Commons license, unless indicated otherwise in a credit line to the material. If material is not included in the article's Creative Commons license and your intended use is not permitted by statutory regulation or exceeds the permitted use, you will need to obtain permission directly from the copyright holder. To view a copy of this license, visit http://creativecommons.org/ licenses/by/4.0/.

(C) The Author(s) 2018 